\title{
Efficacy and Safety of Adrenergic Alpha-1 Receptor Antagonists in Older Adults: A Systematic Review and Meta-analysis for the Development of Recommendations to Reduce Potentially Inappropriate Prescribing
}

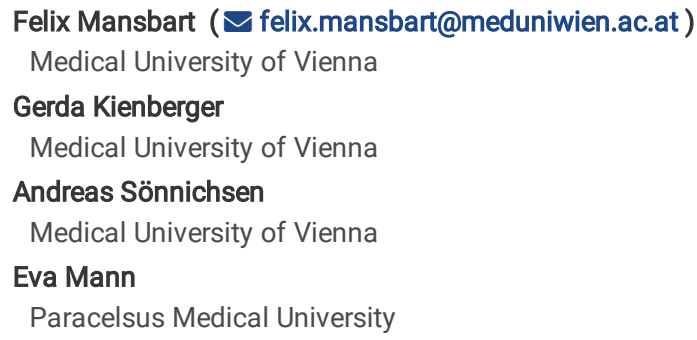




\section{Abstract}

Background

Adrenergic alpha-1 receptor antagonists (alpha-1 antagonists) are frequently used medications in the management of lower urinary tract symptoms (LUTS) suggestive of benign prostatic hyperplasia (BPH) and in the management of therapy-resistant arterial hypertension, two conditions frequently found in older adults. This systematic review aims at presenting a complete overview of evidence over the benefits and risks of alpha- 1 antagonist treatment in people $\geq 65$ years, and at deriving recommendations for a safe application of alpha- 1 antagonists in older adults from the evidence found.

Methods

A comprehensive literature search was performed including multiple databases (Medline/Pubmed, Embase, the Cochrane Library) and using the PICOS framework to define search terms. The selection of the studies was done by two independent reviewers in a two-step approach, followed by a systematic data extraction. Quality appraisal was performed for each study included using standardised appraisal tools. The studies retrieved and additional literature were used for the development of recommendations, which were rated for strength and quality according to the GRADE methodology.

Results

Fourteen studies were included: 3 meta-analyses, 6 randomised controlled trials and 5 observational trials. Doxazosin in the management of arterial hypertension was associated with a higher risk of cardiovascular disease, particularly heart failure, than chlorthalidone. Regarding treatment of LUTS suggestive of BPH, alpha-1 antagonists appeared to be effective in the relief of urinary symptoms and improvement of quality of life. They seemed to be less effective in preventing disease progression. Analyses of the risk profile indicated an increase in vasodilation related adverse events and sexual adverse events for some agents. One large observational study points at an increased risk of falls and fractures. The effects of long-term treatment remained unclear. All meta-analyses and 5 out of 6 interventional studies were downgraded in the quality appraisal. 4 out of 5 observational studies were of good quality.

Conclusions

It cannot be recommended to use doxazosin as first-line antihypertensive agent neither in older adults nor in younger patients. In the management of BPH alpha-1 antagonists promise to effectively relieve urinary symptoms with uncertainty regarding their efficacy in preventing long-term progression events.

\section{Background}

Alpha-1 antagonists are widely used agents predominantly in the treatment of arterial hypertension [1] and, since the late 1980s and early 1990s, LUTS suggestive of BPH [2-5]. Both conditions are very common worldwide [6, 7], especially prominent in the older population and expected to further increase in prevalence [8-10].

LUTS suggestive of BPH only concerns male patients, mostly older, and includes a number of symptoms such as frequency, nocturia, urgency, weak stream or interruption during micturition, high post-void residual volume in the urinary bladder or the difficulty initiating micturition [7]. Recent estimates indicate that almost $50 \%$ of men aged 50 years or older suffer from LUTS as a consequence of BPH and $80 \%$ of males over the age of 80 years [11]. In the US, prevalence numbers have developed substantially over the past years and it is expected that this trend will continue as the population ages [7].

A similar picture can be drawn for hypertension. According to Chow et al. [6] global prevalence figures for hypertension in adults are around $30 \%$ to $45 \%$ with this number being similar across the world and independent of the country's income status. Age, however, does play an important role in the prevalence of hypertension as rates increase with progressing age. This results in shares of more than $60 \%$ in people with 60 years or more and about $75 \%$ in people over the age of 75 years [1]. It is currently forecasted that the number of people with hypertension will rise by $15 \%$ to $20 \%$ until 2025 resulting in approximately 1.5 billion affected people worldwide [8].

The use of alpha- 1 antagonists in the therapy of hypertension is based on the modulation of vessel tone and systemic vascular resistance, which results in an increase in venous capacitance and lowering of blood pressure [12]. As alpha-1 adrenergic antagonists cause a relaxation of smooth muscle both in the vascular system and in the prostate [13], they are also effective in the therapy of LUTS suggestive of BPH reducing the symptoms by up to 50\% [14]. Longterm studies showed no reduction in prostate size nor prevention of acute urinary retention events, though [15-17]. The most common adverse side effects include dizziness, postural hypotension, asthenia, headache, rhinitis and ejaculatory dysfunction occurring in about $5 \%$ to $9 \%$ of the patients [18].

The medical treatment of older adults comes with many challenges. On the one hand, it is known that pharmacodynamics as well as pharmacokinetics differ between younger patients and older patients [19] leading to an increased risk of developing ADEs among the elderly [20]. On the other hand, older adults are more frequently affected by multimorbidity, which may result in polypharmacy [21] and this again increases the risk of ADEs, adverse drug interactions, and possibly hospitalisation [22-24]. The versions of diverse national PIM (potentially inadequate medication for the elderly) lists are inconclusive on how to categorize alpha-1 antagonists. Doxazosin is included in three PIM lists [25-27], two of which also include terazosin [25, 27]. PIM lists of Austria, France and Canada do not include any of the alpha-1 antagonist [28-30].

In the light of the above-mentioned it seems overdue to summarize and synthesize the evidence available on the treatment of elderly with alpha- 1 antagonists. An ageing population associated with an expected substantial increase of the prevalence of hypertension and LUTS suggestive of BPH in the near future will lead to an increased use of alpha- 1 antagonists in patients older than 65 years. The aim of this systematic review is to explore the effectiveness and safety of alpha-1 antagonists in these patients and to develop recommendations on when to discontinue or reduce the dose of alpha-1 antagonists to prevent inappropriate prescribing. 
To the best of our knowledge, so far, no systematic review has analysed the specific evidence on the use of alpha- 1 antagonists in the aged population.

The aims of this SR are therefore to

- systematically review the literature on the risks and benefits of the use of alpha- 1 antagonists in older adults ( $\geq 65$ years),

- critically assess the quality of evidence identified, and

- develop recommendations for or against the use of alpha-1 antagonists in older adults.

\section{Methods}

This systematic review was developed and conducted with reference to the methodology as described in the Cochrane Handbook for Systematic Reviews of Interventions [31].

The study protocol was registered at the international prospective register of systematic reviews (CRD42020183345).

\section{Search method}

A thorough review of existing research literature was carried out in a three-stage process. In the first stage, a highly sensitive search was performed in order not to miss out on any relevant studies. In steps two and three papers with irrelevant content according to the inclusion and exclusion criteria were removed.

\section{Development of the search terms}

For step one search terms were developed in accordance with the PICOS model for each of the following categories: population, intervention, comparison, outcomes and study design. The terms within each category were connected by "OR" in the search process while the terms of different categories were connected by "AND". As Medline/Pubmed was used as a search engine, the official MeSH terms or its entry terms were applied as search terms (see Additional file 1 for full list of search terms).

\section{Step 1 - literature search}

The search was performed in Medline/Pubmed, Embase and the Cochrane Database of Systematic Reviews. The result of the literature search was uploaded to Endnote X8.2 software for data management purposes. Duplicates were removed and step two (selection of studies) was performed with the help of Endnote.

Complementary to the literature search the citations of included studies were examined in order not to miss any important study.

\section{Steps $2 \& 3$ - selection of studies}

For the second step, two reviewers (FM and GK) worked through the list of research papers derived from step one by independently assessing the relevance of each study's title and abstract. The assessment was based on the inclusion and exclusion criteria defined beforehand (for details, see below). If a paper seemingly met the inclusion criteria the study was included for step three. Research papers evidently not relevant for this systematic review were excluded. Upon conclusion of step two and before starting step three the reviewers compared their results. Studies selected by both were then automatically included in step three. If there were research papers selected by only one of the two, the reviewers had to re-evaluate and discuss to come to a mutual agreement. In case of an unresolvable disagreement a third reviewer (AS) was consulted and asked to decide.

The same procedure was applied to step three but now the assessment was based on the full manuscript of all studies selected in step two. The research papers selected in step three met all inclusion criteria and were therefore incorporated in this systematic review.

\section{Inclusion and exclusion criteria}

\section{Types of studies}

The following types of studies were included: systematic reviews, meta-analyses, interventional studies and observational studies. Other study types were excluded, e.g. narrative reviews, expert opinions, case reports or letters.

\section{Types of participants}

Studies were only eligible if they reported results for older adults. The term older adults was defined as people with the age of 65 years or older. We included studies if the mean age minus 1.8 times the standard deviation was 65 years or older or if there was separate reporting for age subgroups equal to or greater than 65 years.

\section{Types of interventions}

Studies were only included if the intervention lasted for at least 4 weeks. Analyses on acute care and short-term treatment were thus excluded. In addition, the intervention had to include an alpha-1 antagonist (e.g. tamsulosin, doxazosin, alfuzosin) and a comparator. Such comparator could be no treatment, placebo, other drug (also different alpha-1 antagonists), phytotherapy or other non-pharmacological interventions. Studies without a comparator were excluded. 


\section{Types of outcomes}

Studies were deemed eligible if they investigated direct patient relevant outcomes such as efficacy or effectiveness (e.g. change in the International Prostate Symptom Score [IPSS]) and/or ADEs (e.g. dizziness, asthenia, falls) and/or long-term drug safety (e.g. cognitive decline, cardiovascular events) as well as QoL, mortality, and/or hospitalisations. It was irrelevant for the inclusion of a study whether these outcomes were defined as primary or secondary outcomes. Studies only investigating surrogate parameters (e.g. asymptomatic changes in blood pressure as a proxy for orthostatic hypotension) were excluded.

\section{Publication dates}

No limit was set regarding publication dates.

\section{Language}

Studies were only included if they were written in English or German.

\section{Data extraction}

All relevant data from included studies was extracted. Data was deemed relevant if it met all criteria to answer the research questions of this systematic review. It is therefore possible that only parts of the results of an entire study were extracted, e.g. subgroup analysis for study participants with the age of 65 years or older.

Standardised data collection forms were used for the data extraction. Results include tables for

- the summary of characteristics of included studies,

- the summary of patient characteristics of included studies, and

- the summary of study findings of included studies.

Each of them is specific to the study designs included (i.e. meta-analyses, interventional studies, and observational studies). Data extraction was reviewed by a second researcher and checked for completeness, accuracy, and relevance.

\section{Data synthesis/Meta-analyses}

It was intended to perform a meta-analysis with the included results if reasonably doable with the respective data. Review Manager, version 5.3, was used for computations and the creation of figures [32].

\section{Quality appraisal}

A critical assessment of the methodological quality was performed for each included study. Established and validated appraisal tools were therefore used depending on the respective study type. Interventional studies were evaluated with the Revised Cochrane Risk-of-Bias Tool for Randomised Trials (RoB 2) [33] Observational studies were assessed by using the checklists offered by Critical Appraisal Skills Programme (CASP) on the critical appraisal of case-control studies [34] and cohort studies [35]. Systematic reviews including meta-analyses were assessed with AMSTAR 2, an instrument developed for the measurement and assessment of systematic reviews [36].

\section{Development of recommendations}

Recommendations on the use of alpha- 1 antagonists in patients aged $\geq 65$ years were developed based on the findings of this systematic review supplemented with additional references. A specific non-systematic literature search was therefore performed in the Cochrane Database of Systematic Reviews and Medline/Pubmed including papers found during steps two and three of the search for this systematic review and studies found by snowballing. In addition, the most recent evidence based guidelines for the treatment of hypertension by the European Society of Hypertension (ESH) and the European Society of Cardiology (ESC) [37] and for the treatment of non-neurogenic male LUTS by the European Association of Urology (EAU) [38] were consulted and its references screened. Each recommendation was rated with respect to strength (weak or strong) and quality (high, moderate, low, very low) [39-41] according to the Grading of Recommendations Assessment, Development and Evaluation (GRADE) methodology.

\section{Results}

Results of the search

2586 records could be identified through the first step of the systematic review process, out of which 36 duplicates were immediately removed. No additional records were identified through other sources. 2550 research papers were screened during the second step, out of which 2176 could be excluded based on title and abstract. The remaining 374 records were assessed for eligibility based on full texts. 360 full texts were excluded in step three, resulting in fourteen studies, which were included in this systematic review. Additional file 2 lists all research papers excluded in the last step individually with the respective reason for exclusion. Figure 1 shows the PRISMA flow diagram [42].

Characteristics of included studies 
Fourteen studies were included in this systematic review, out of which six are interventional studies [43-48], five are observational studies, three cohort studies [49-51] and two case-control studies [52,53], and three are meta-analyses, two including two [54, 55] and one including six [56] randomised controlled trials. The trials' geographical focus was mainly on the United States of America (US), European countries and Japan. Follow-up was minimum 4 weeks [45, 54] and the longest lasting trial had a mean follow-up period of 3.2 years [43]. For a detailed summary of the characteristics of included studies please refer to Additional file 3.

Characteristics of study participants

The age structure of participants varied as inclusion criteria were defined differently between studies. All three meta-analyses [54-56] and three interventional studies $[43,46,47]$ had a broad age distribution but offered age related subgroup analyses. Two interventional studies [44, 48] set minimum age below 65 years but were included entirely as they met the age eligibility criteria as defined above and one interventional study [45] enrolled only patients aged 66 years or older. Four observational trials only included older adults [49-51, 53], one looked at younger patients also but presented relevant age-related content [52]. With the exception of the Antihypertensive and Lipid-Lowering Treatment to Prevent Heart Attack Trial (ALLHAT) study [43] and the Syncope and Dementia study [53], all trials included only men focusing on LUTS suggestive of BPH. See Additional file 4 for a summary of the patient characteristics of included studies. Refer to Additional file 5 for further details on patient characteristics for each study used in the included meta-analyses.

Interventions and outcomes

For detailed information on the interventions and outcomes of included studies please refer to Additional file 3.

Doxazosin

Two studies focused particularly on doxazosin $[43,52]$. The ALLHAT study $(2003)$ compared the efficacy of doxazosin and chlorthalidone in reducing cardiovascular events (e.g. fatal coronary heart diseas or combined cardiovascular disease) in hypertensive patients [43]. Hall and McMahon (2007) performed a retrospective observational study and investigated the relation of exposure to doxazosin and the incidence of fractures (e.g. hip, femur) [52].

Tamsulosin, naftopidil and silodosin

Four interventional studies examined the efficacy of tamsulosin [44-46, 48], whereas two observational studies [50, 51] and one meta-analysis [55] explored particular side effects. Oelke et al. (2014) compared treatment satisfaction between tamsulosin and placebo or tadalafil in patients with urinary symptoms related to BPH [46]. Three further interventional studies assessed the efficacy of tamsulosin against naftopidil $[44,45,48]$ and silodosin $[48]$ with regard to the reduction of urinary symptoms according to the IPSS, the increase of QoL and, with the exception of Yokoyama et al. (2011) [48], the occurrence of ADEs. Two meta-analyses could be performed comparing pre to post drug administration data for tamsulosin with regard to change in IPSS and QoL [44, 45, 48]. One additional meta-analysis was performed to compare the occurrence of ADEs between tamsulosin and naftopidil [44, 48]. Chapple et al. (1997) compared the safety and tolerability of tamsulosin with placebo in older patients with LUTS suggestive of BPH [55]. Duan et al. (2018) explored the association of tamsulosin use and the risk of dementia by comparing to no BPH medication and alternative treatment options [50]. Welk et al. (2015) analysed the occurrence of falls in tamsulosin users [51].

Alfuzosin

Roehrborn (2006) explored the occurrence of progression events due to BPH (i.e. worsening of IPSS, BPH related surgery and acute urinary retention events) in patients taking alfuzosin $10 \mathrm{mg}$ per day controlled against placebo over a period of 24 months [47]. A meta-analysis by Buzelin et al. (1997) analysed the incidence of ADEs from two randomised controlled trials [54].

Terazosin

Lowe et al. (1994) performed a meta-analysis and therefore amalgamated the data of six randomised controlled trials to assess the safety of terazosin use in the treatment of $\mathrm{BPH}$ related symptoms [56].

Any alpha-1 antagonist

Three observational studies included several alpha-1 antagonists in their analysis partly without differentiating between single agents. Chrischilles et al. (2001) examined the effect of treatment initiation with terazosin, doxazosin or prazosin on hypotension related adverse events [49]. Testa et al. (2018) analysed the role of antihypertensive drugs including alpha-1 antagonists in the occurrence of orthostatic hypotension related syncopes in people with dementia [53]. Welk et al. (2015) elaborated on the effect of treatment initiation with tamsulosin, alfuzosin or silodosin on the risk for fractures and falls [51].

Main findings

The results of the included studies are structured and summarised by outcome below. Please refer to Tables 1-3 for a detailed display of the study results.

Cardiovascular events

Results from the ALLHAT study (2003) showed an increased risk of doxazosin compared to chlorthalidone for combined cardiovascular events (i.e. death from coronary heart disease, nonfatal myocardial infarction, stroke, coronary revascularisation, hospitalised or treated angina, treated or hospitalised congestive heart failure, and peripheral artery disease and heart failure). The combined cardiovascular risk is elevated among patients $<65$ years (relative risk

Page $5 / 24$ 
RR $1.15,95 \%$ confidence interval $\mathrm{Cl} 1.04-1.27)$ and more pronounced for patients $\geq 65$ years (RR $1.23,95 \% \mathrm{Cl} 1.14-1.32)$. The results for heart failure for participants $<65$ years of age (RR $1.76,95 \% \mathrm{Cl} 1.40-2.22)$ and participants $\geq 65$ years (RR $1.89,95 \% \mathrm{Cl} 1.65-2.17)$ are even clearer [43].

Efficacy in reducing BPH related symptoms

Significant improvement of IPSS for tamsulosin in a pre-post comparison was demonstrated by Gotoh et al. (2005) (mean reduction -8.4, 95\% Cl-10 - (-6.8); $\mathrm{p}$ < 0.001) [44], Nishino et al. (2005) (mean score [standard deviation (SD)] 20.4 [3.5] vs. 9.3 [3.0]; p < 0.001) [45] and Yokoyama et al. (2011) (mean score [SD] 18.0 [1.1] vs. 10.7 [1.4]; $p<0.001$ ) [48]. Similar results were reported for naftopidil in the same studies. Silodosin was only investigated in one study conducted by Yokoyama et al. (2011) with comparable results [48]. Significance in superiority of one agent over another could not be demonstrated with intergroup $\mathrm{p}$ values at $0.060[44], 0.265[45]$ and $>0.05[48]$.

A meta-analysis was performed to consolidate the results for tamsulosin $0.2 \mathrm{mg}$ comparing results pre vs. post administration. Tamsulosin was chosen due to its importance on the European market as compared with naftopidil. The result favours the intervention with tamsulosin $0.2 \mathrm{mg}$ (post administration) over no intervention (pre administration) showing a significant reduction in urinary symptoms (mean difference $-8.86,95 \% \mathrm{Cl}-11.14--6.58$; see figure 2 ).

Progression events from BPH associated LUTS

In a two-year follow up, the results of Roehrborn (2006) showed that alfuzosin has a non-significant positive effect on slowing down the progression of the IPSS (RR $0.84,95 \% \mathrm{Cl} 0.62-1.15)$ and the need for $\mathrm{BPH}$ related surgery (RR $0.64,95 \% \mathrm{Cl} 0.36-1.12$ ) and no effect on the reduction of acute urinary retention events (RR $0.98,95 \% \mathrm{Cl} 0.39-2.44)$ in patients over the age of 65 years [47].

Treatment satisfaction and QoL

The results of Oelke et al. (2014) showed no significantly better scores in treatment satisfaction of patients > 65 years with LUTS suggestive of BPH when treated with tamsulosin than with placebo (mean score [SD] 32.4 [15.8] vs. 32.2 [17.9]; p-value $=0.759$ ) [46].

In a pre-post comparison, significant improvement in QoL was demonstrated for tamsulosin, naftopidil and silodosin in three trials [44, 45, 48]. Significant differences in the improvement of QoL-scores between tamsulosin, naftopidil and silodosin could not be demonstrated with intergroup p-values at 0.801 [44], $0.201[45]$ and $>0.05[48]$.

A meta-analysis was performed to consolidate the results for tamsulosin $0.2 \mathrm{mg}$ comparing results pre vs. post administration. The result favours the intervention with tamsulosin $0.2 \mathrm{mg}$ (post administration) over no intervention (pre administration) showing a significant improvement in QoL of patients with LUTS (mean difference -1.77, 95\% $\mathrm{Cl}-2.11--1.43$; see figure 3 ).

ADEs

Chapple et al. (1997) conducted a safety analysis for tamsulosin compared with placebo in 291 older patients and found no significant difference in the occurrence of any adverse events between groups (tamsulosin: 70/191, 37\%; placebo: 31/100, 31\%; $p=0.330$ ) or adverse events, which were considered drugrelated (tamsulosin: 23/191, 12\%; placebo: 9/100, 9\%; $p=0.459$ ) or adverse events possibly associated with vasodilation (tamsulosin: $8 / 191,4.2 \%$; placebo: 4/100, 4\%; $p=0.523$ ) [55]. Buzelin et al. (1997) reported an almost equal distribution of ADEs comparing alfuzosin with placebo (alfuzosin: 12/149, 8.1\%; placebo: 12/153, 7.8\%). Also, adverse events related to vasodilation (alfuzosin: 2/149, 1.3\%; placebo: 2/153, 1.3\%) occurred evenly between both groups [54]. Lowe et al. (1994) provided a more detailed analysis on different specific ADEs (see Table 3) [56].Three interventional studies reported on ADEs and found no significant differences between agents $[44,45,48]$.

A meta-analysis was undertaken to combine the results of three interventional studies assessing the occurrence of ADEs for treatment with tamsulosin or naftopidil $[44,45,48]$. The result shows no significant differences between these two agents (odds ratio $0.96,95 \% \mathrm{Cl} 0.38-2.40$; see figure 4 ).

Syncope and hypotension

Testa et al. (2018) presented results indicative of the fact that alpha-1 antagonist use may play a role in orthostatic hypotension related syncopes in adults with dementia especially when taken concomitantly with diuretics (adjusted for age and sex RR 1.83, 95\% $\mathrm{Cl} 0.85-3.96$ ) [53].

The effect of treatment initiation with alpha-1 antagonists on hypotension and hypotension related adverse events was examined by two observational studies. The numbers reported by Chrischilles et al. (2001) showed a significant difference between the alpha-1 antagonist cohort and no alpha- 1 antagonist cohort when comparing incidence rates of hypotension related ADEs one month before treatment initiation with the first month after $(p$-value $=0.001)$ [49]. Welk et al. (2015) demonstrated an increased risk for hospitalisation or emergency room assessment due to hypotension (Odds ratio [OR] 1.80, 95\% $\mathrm{Cl} 1.59-$ 2.03) within 90 days after treatment initiation with alpha-1 antagonists tamsulosin, alfuzosin or silodosin [51].

Falls and fractures

Welk et al. (2015) demonstrated a correlation of initiation of alpha-1 antagonist treatment and new fracture (OR 1.16, 95\% $\mathrm{Cl} 1.07-1.21)$, head trauma (OR $1.15,95 \% \mathrm{Cl} 1.04-1.27)$ and falls (OR 1.14, 95\% Cl $1.07-1.21)$. Agent specific results for falls differed between tamsulosin, alfuzosin and silodosin [51]. In contrast, Hall and McMahon (2007) could not show an association between fractures commonly due to falls (i.e. hip/femur, wrist and humerus) and initiation of doxazosin use (OR $0.57,95 \% \mathrm{Cl} 0.17-1.92$ ), current doxazosin use (adjusted OR $0.90,95 \% \mathrm{Cl} 0.68-1.19$ ) or any previous doxazosin use (adjusted OR $0.92,95 \% \mathrm{Cl} 0.69-1.23)$ [52]. 
Ejaculation disorders

Participants receiving silodosin showed a high percentage of ejaculation disorders after 4 weeks of treatment (10/11, 90,9\%) and after 12 weeks of treatment (8/10, 80\%) whereas tamsulosin (4 weeks: 1/12, 8,3\%; 12 weeks: 1/5, 20\%) and naftopidil (4 weeks: 1/15, 6,7\%; 12 weeks: 1/14, 7,1\%) did not [48]. Chapple et al. (1997) reported on elevated numbers of abnormal ejaculations during treatment with tamsulosin compared to placebo (tamsulosin: $5 / 191,2.6 \%$; placebo: $1 / 100,1 \% ; p=0.668)[55]$.

Dementia

Duan et al. (2018) found significant increases in the incidence of dementia when tamsulosin was compared to no BPH medication (hazard ratio (HR) 1.17, $95 \% \mathrm{Cl} 1.14-1.21$ ), to doxazosin (HR 1.20,95\% Cl $1.12-1.28$ ), to terazosin (HR 1.11,95\% Cl $1.04-1.19$ ), and to alfuzosin (HR $1.12,95 \% \mathrm{Cl} 1.03-1.22)$ as well as dutasteride (HR 1.26, 95\% Cl 1.19 - 1.34) and finasteride (HR $1.13,95 \% \mathrm{Cl} 1.07-1.19)$ [50].

Quality appraisal of included studies

Meta-analyses

None of the included meta-analyses [54-56] met any of the criteria defined in the AMSTAR 2 assessment tool [36] with the exception of statement of funding. Neither of the publications provide detailed information on the methodology used. All meta-analyses used unpublished information and presumably based their analysis on raw data. Due to a lack of transparency on the calculations performed the figures published cannot be reconstructed neither is it possible to assess homogeneity of the data or likelihood of publication bias of included studies. A comprehensible reproduction of the results is therefore not possible. See Table 4 for details on quality appraisal.

Interventional studies

The result of the assessment for risk of bias based on the appraisal of five different categories according to the RoB 2 tool [33] is shown for each study in Table 5.

The overall risk-of-bias judgement was "low risk" for one study [43], one study was rated with "some concerns" [45] and four trials were graded "high risk" [44, 46-48]. Selection bias arising from randomization of the patients raised some concerns in the trial by Gotoh et al. (2005) as baseline characteristics in the categories total IPSS ( $p$-value $=0.088$ ) and prostate volume $(p$-value $=0,06)$ were imbalanced between the two interventional groups [44]. Four studies were classified as "high risk" for attrition bias due to a high share of dropouts ranging from $11,2 \%$ [46] to 33,7\% [47], either in large part attributable to the intervention [46-48] or without delivering comprehensible data [44]. Some concerns were raised for three trials [44, 45, 48] due to missing information on blinding of participants and potential influence on the self-assessment in the IPSS. The same studies were also downgraded to some concerns for reporting bias as none of them provided a study protocol. It must be considered that the doxazosin component of the ALLHAT study was stopped prematurely due to higher rates of heart failure and combined cardiovascular events [43].

Observational studies

Five observational studies were included and their risk of bias assessed in accordance to their study type, three retrospective cohort studies [49-51] and two case-control studies [52,53]. Except for one [49] all studies were well rated on the majority of CASP items and can therefore be considered good quality. For details, refer to Tables 6 and 7 .

Sponsoring and conflict of interest of included studies

Eleven of fourteen included studies reported about conflict of interest and study sponsors $[43,45-47,49-53,55,56]$, seven of which reported direct or indirect funding by pharmaceutical companies $[43,46,47,49,52,55,56]$. Three studies reported support from national institutes [43, 50, 51], one was university funded [45] and one study was endorsed by a local society [53]. Three studies did not give any information on potential sources of conflict of interest [44, 48, 54].

Additional references of interest for the development of recommendations

Two evidence based guidelines [37, 38], two Cochrane reviews [57, 58], one network meta-analysis [59] and four systematic reviews [60-63], three of them including a meta-analysis, were identified and incorporated into the recommendations in addition to four randomised controlled trials included in this systematic review $[43-45,48]$. All the additional literature was not included in the systematic review due to their missing focus on the age subgroup of people $\geq 65$ years but was deemed relevant as additional information was retrieved concerning efficacy and risk profile of alpha- 1 antagonists.

Nickel et al. (2008) reported about significant improvements in IPSS for alfuzosin, terazosin, doxazosin and tamsulosin with no statistically significant differences between substances [62]. Similar findings were reported by Djavan et al. (2004) [63] and Yuan et al. (2015) [59]. Fusco performed two metaanalyses in 2016 and 2018 indirectly confirming these results as significant improvements in the Bladder Outlet Obstruction Index (BOOI) could be shown for alfuzosin, terazosin, doxazosin, tamsulosin, naftopidil and silodosin [60,61]. Jung et al. (2017) conducted a Cochrane review on silodosin and reported significant improvement in IPSS and QoL versus placebo but no substantial differences when compared to tamsulosin or alfuzosin [57]. Hwang et al. (2018) focused on naftopidil in their Cochrane review with no significant differences in IPSS and QoL when compared with tamsulosin or silodosin [58]. Regarding drug safety, two main areas of interest were covered by the additional references being vasodilation related ADEs (e.g. dizziness, hypotension, syncope) and sexual ADEs. A significant increase in vasodilation related ADEs was reported by Nickel et al. (2008) for alfuzosin, terazosin and doxazosin, a clear tendency 
but not significant $(p=0.053)$ for tamsulosin [62]. Similar results have been mentioned by Djavan et al. (2004) [63]. Yuan et al. (2015) demonstrated significantly increased total ADEs for doxazosin, terazosin and silodosin and a tendency, but insignificant, towards increased severe adverse events for doxazosin and terazosin [59]. Silodosin significantly increased rates of sexual adverse events in all comparisons [57]. Treatment with naftopidil compared with tamsulosin and silodosin showed no difference in cardiovascular risk profile or withdrawal rates but significantly less sexual adverse events than for silodosin [58].

\section{Recommendations}

Two recommendations were developed based on the findings of this systematic review and additional references of interest as stated above (see Table 8 for recommendations). One recommendation is related to the management of bothersome LUTS suggestive of BPH. Alpha- 1 antagonists prove to be effective in the reduction of the IPSS, an internationally used and validated score to measure urinary symptoms, while having an acceptable risk profile. The ADEs differ between agents and therefore have to be considered on a patient-oriented basis. The recommendation was based on three randomised controlled trials included in this systematic review [44,45,48], the most recent version of the guideline for the management of non-neurogenic male LUTS by the EAU [38], two Cochrane reviews [57, 58], and four systematic reviews including meta-analysis [60-63]. The recommendation was given the following ratings: strong recommendation and low in quality. The quality was downgraded from high to low due to study limitations in the randomised controlled trials and indirectness of additional references.Based on the findings of the ALLHAT study [43] and the $2018 \mathrm{ESC} / \mathrm{ESH}$ guidelines for the management of arterial hypertension [37] the second recommendation is to replace doxazosin with another antihypertensive drug in the treatment of hypertension. The recommendation was rated as strong recommendation and of high quality.

\section{Discussion}

This systematic review was performed to summarize the current body of knowledge about the efficacy/effectiveness as well as the safety profile of alpha-1 antagonists in the management of arterial hypertension and LUTS suggestive of BPH in patients $\geq 65$ years and to derive recommendations on the use of alpha-1 antagonists in the subgroup of older adults.

\section{Summary of main results}

Fourteen studies were included in this systematic review: three meta-analyses, six randomised controlled trials, three cohort studies and two case-control studies. The studies varied in terms of geographical focus, length of follow-up (shortest 4 weeks; longest 3.2 years), characteristics of participants, interventions, and outcomes. One study analysed the efficacy of doxazosin in the management of arterial hypertension. The other trials studied alpha- 1 antagonists in the management of LUTS suggestive of BPH. The included studies reported on cardiovascular outcomes, change in IPSS, QoL, treatment satisfaction, disease progression and typical ADEs such as vasodilatory adverse events (e.g. dizziness, syncope, falls, fractures) and sexual adverse events as well as dementia. Only one study reported on mortality. Based on the results of included studies it was possible to perform meta-analyses on three different outcomes: occurrence of ADEs, change in IPSS, and change in QoL-score.

Doxazosin, used as an antihypertensive medication in older patients, seems to be inferior to chlorthalidone in reducing cardiovascular risk and especially heart failure. Alpha- 1 antagonists seem to be effective in patients $\geq 65$ years in reducing lower urinary tract symptoms due to BPH reflected by a substantial decrease of the IPSS and an increase in QoL. The study results point out certain ADEs but are inconclusive in defining a reliable risk profile for any of the alpha-1 antagonists. Alpha-1 antagonists may produce certain ADEs due to vasodilation and ejaculatory disorders with differences between substances. There is inconclusive data on the effect of alpha- 1 antagonists on fractures and falls and an indication for increased incidence rates of dementia in the longerterm use of tamsulosin.

Two recommendations could be derived from the results for older adults. One concerning the role of doxazosin in the management of arterial hypertension and the other regarding the role of alpha-1 antagonists in the treatment of LUTS suggestive of BPH.

Agreements and disagreements with other studies or reviews

To the best of our knowledge, the findings of the ALLHAT study have never been reproduced since. The Anglo-Scandinavian Cardiac Outcomes Trial (ASCOT) trial [64] examined the effect of doxazosin as third-line antihypertensive therapy in resistant hypertension and found no excess of heart failure over a median follow-up of 12 months. Wolak et al. (2014) found a significant increase in the composite of cardiac death and acute myocardial infarction in patients being treated with doxazosin for hypertension (as opposed to treatment for LUTS) with a moderate-to-severe ischemia on myocardial perfusion imaging. There was no focus on heart failure [65]. Neither of the studies published subgroup analyses for patients $\geq 65$ years.

Three randomised controlled trials $[44,45,48]$ approved of the efficacy of tamsulosin and other alpha- 1 antagonists in the reduction of urinary symptoms in older adults and improvement of QoL, which had previously been shown in several trials without focus on the specific age subgroup [57-63]. As regards the agents' risk profiles comparable results were reported for tamsulosin, silodosin and naftopidil with a higher occurrence of sexual adverse events for silodosin $[44,45,48,57,58]$.

Nickel et al. (2008) show significantly increased vasodilation related adverse events (i.e. dizziness, hypotension, syncope) for alfuzosin, terazosin, doxazosin and almost significant for tamsulosin [62]. Similar results were calculated by Yuan et al. (2015) in their network meta-analysis [59]. This corresponds to the findings on a rise in hypotension related adverse events [49] and fractures and falls [51] upon treatment initiation with doxazosin/terazosin/prazosin and tamsulosin/silodosin/alfuzosin, respectively. Hall and McMahon (2007), however, could not show any association between modified release doxazosin use and fractures typical for falls [52]. As opposed to the results of most of the literature reporting significant improvement in symptom scores and QoL scores, Oelke et al. (2014) could not show considerably better treatment satisfaction scores in older adults for tamsulosin than for placebo [46]. 
Most findings of this systematic review confirm the important standing of alpha-1 antagnonists in the management of patients with LUTS suggestive of BPH and the minor role of doxazosin in the management of arterial hypertension. Nevertheless, some issues must be addressed concerning the applicability of the results.

The short follow-up time limits the the ability to appraise the effects in long-term treatment with alpha-1 antagonists in LUTS suggestive of BPH [44, 45, 48]. The applicability of the results is additionally impaired as the dose regime used for tamsulosin was $0.2 \mathrm{mg}$ once daily in all three trials, which is lower than the recommended daily dose of tamsulosin $0.4 \mathrm{mg}$ in Western countries. It also has to be considered that the trials were not placebo controlled. Whether alpha- 1 antagonists can be recommended for long-term treatment remains doubtful as the results by Roehrborn et al. (2006) demonstrate similar progression event rates for treatment with alfuzosin as for placebo [47] and a retrospective cohort study of 2018 revealed a possible relationship between tamsulosin and the incidence of dementia [50]. Other classes of drugs such as 5alpha-reductase inhibitors (e.g. dutasteride, finasteride) or phosphodiesterase type 5 inhibitors (e.g. tadalafil) are currently being used in the management of LUTS suggestive of BPH alone or in combination with alpha-1 antagonists [38]. Only one study compared treatment satisfaction between management with tamsulosin $0.4 \mathrm{mg}$, tadalafil $5 \mathrm{mg}$ and placebo but did not offer separate reporting for older adults [46]. Therefore, no valuable additive information regarding the comparison or combination of treatments in older adults could be delivered by this systematic review.

Limitations and potential biases

A thorough search process was carried out including the application of the PICOS scheme and a two-step approach in the selection of eligible studies thereafter. Nevertheless, it is possible that relevant publications might have been missed as the detection of studies was limited to the databases used.

The results of the meta-analyses must be interpreted with caution. Due to high heterogeneity between included studies the meta-analyses combined the results of only three studies in the case of effect on change of IPSS and QoL-score and two in the case of ADEs. The low number of studies and imputation of $\mathrm{SD}$ values due to non-reporting in the original studies reduce the validity of results considerably.

Several sources not focusing particularly on people $\geq 65$ years were included for the formulation of the recommendations. Although the additional sources demonstrated similar effects for all age classes the information base may be regarded as diluted. Publication bias has to be regarded as a potential source of bias and could not be assessed due to methodological inconsistencies and the heterogeneity of outcomes. The quality of evidence was evaluated using established and validated quality appraisal tools. Except for one interventional trial [43] all randomised controlled trials were downgraded mostly due to unclear dealing with missing outcome data (attrition bias) and missing study protocol (reporting bias). The authors with missing study protocols were contacted via e-mail but none responded to the request. The quality of included meta-analyses was labelled low quality and most observational studies were rated good quality.

\section{Conclusion}

Implications for practice

The use of doxazosin should not be considered as first-line medication for the management of arterial hypertension. The use of alpha-1 antagonists in the management of LUTS suggestive of BPH, however, appears to be promising in reducing urinary symptoms. Thereby, the safety profile of different agents has to be carefully assessed in a patient-oriented manner. Long-term safety and efficacy remain questionable and an assessment of efficacy and safety profile in comparison with other classes of drugs could not be performed.

Implications for research

Even though many older adults suffer from hypertension and the majority of older men experience LUTS from BPH, only fourteen eligible studies could be identified, primarily due to the age restriction. This highlights the lack of evidence for older adults although the largest part of medical interventions is performed in this age class. Additionally, randomised controlled trials with extended follow-up periods are needed to assess the benefits and risks of alpha- 1 antagonist treatment in long-term use, providing an enhanced understanding of the real-world use of these medications. To complete the picture of management of LUTS suggestive of BPH in people $\geq 65$ years it would be also desirable if future research would focus on comparisons and combinations of different classes of drugs.

Given that most included studies revealed considerable methodological limitations a stronger emphasis should be laid on the application of appropriate methodology. This would produce higher quality results yielding more reliable evidence helping us all to provide the best possible patient care.

\section{Abbreviations}




\begin{tabular}{|c|c|}
\hline ACE-inhibitor & Angiotensin converting enzyme inhibitor \\
\hline ADEs & Adverse drug events \\
\hline ALLHAT & Antihypertensive and Lipid-Lowering Treatment to Prevent Heart Attack Trial \\
\hline Alpha- 1 antagonists & Adrenergic alpha-1 receptor antagonists \\
\hline ASCOT & Anglo-Scandinavian Cardiac Outcomes Trial \\
\hline AUASS & American Urological Association Symptom Score \\
\hline AUR & Acute urinary retention \\
\hline BOOI & Bladder Outlet Obstruction Index \\
\hline $\mathrm{BPH}$ & Benign prostatic hyperplasia \\
\hline CAD & Coronary artery disease \\
\hline CASP & Critical Appraisal Skills Programme \\
\hline CeVD & Cerebrovascular disease \\
\hline $\mathrm{CHD}$ & Coronary heart disease \\
\hline $\mathrm{CHF}$ & Chronic heart failure \\
\hline $\mathrm{Cl}$ & Confidence interval \\
\hline CKD & Chronic kidney disease \\
\hline COPD & Chronic obstructive pulmonary disease \\
\hline $\mathrm{CV}$ & Cardiovascular \\
\hline CVD & Cardiovascular disease \\
\hline DDD & Defined daily dose \\
\hline EAU & European Association of Urology \\
\hline ESC & European Society of Cardiology \\
\hline ESH & European Society of Hypertension \\
\hline ED & Erectile dysfunction \\
\hline FORTA & Fit fOR The Aged \\
\hline GRADE & Grading of Recommendations Assessment, Development and Evaluation \\
\hline HRQL & Health related quality of life \\
\hline IIEF-5 & International Index of Erectile Function \\
\hline IPSS & International Prostate Symptom Score \\
\hline LUTS & Lower urinary tract symptoms \\
\hline mo & months \\
\hline N.a. & Not available \\
\hline NSAID & Non-steroidal anti-inflammatory drug \\
\hline OR & Odds ratio \\
\hline PIM & Potentially inappropriate medication \\
\hline PPI & Proton pump inhibitor \\
\hline PVD & Peripheral vascular disease \\
\hline PVR & Post void residual volume \\
\hline $\mathrm{Q}_{\max }$ & Maximum urinary flow rate \\
\hline QoL & Quality of Life \\
\hline RCTs & Randomized controlled trials \\
\hline $\mathrm{RR}$ & Relative Risk \\
\hline \multirow[t]{2}{*}{$\mathrm{RR}_{\mathrm{dia}}$} & Diastolic blood pressure \\
\hline & Systolic blood pressure \\
\hline
\end{tabular}




\begin{tabular}{|ll|}
\hline RR & \\
Sys & Standard deviation \\
SR & Systematic review \\
\hline SSRI & Selective serotonin reuptake inhibitor \\
\hline TIA & Transient ischemic attack \\
\hline TSS-BPH & Treatment Satisfaction Scale for BPH \\
\hline$V_{\text {prostate }}$ & Prostatic volume \\
\hline$y$ & Years \\
\hline
\end{tabular}

\section{Declarations}

Ethics approval and consent to participate

The ethics commission of the Medical University of Vienna issued a waiver for this systematic review. Therefore, no separate ethics approval is necessary.

Consent for publication

Not needed for this systematic review.

Availability of data and materials

All data generated or analysed during this study are included in this published article [and its supplementary information files].

Competing interests

The authors declare that they have no competing interests.

Funding

The Austrian Principal Association of Social Insurances (Hauptverband der österreichischen Sozialversicherungsträger) acted as sponsor of the PIM-Austria project and provided prescription data used in this systematic review.

Authors' contributions

FM performed the data extraction, analysis and interpretation of data, and quality appraisal. GK also performed the literature research and data extraction. FM and EM prepared the manuscript. AS took part in the design/conception of the work and, together with EM, the revision of it. All authors read and approved the final manuscript.

Acknowledgements

The literature search was performed by university employees.

\section{References}

1. Williams, B., et al., 2018 ESC/ESH Guidelines for the management of arterial hypertension: The Task Force for the management of arterial hypertension of the European Society of Cardiology (ESC) and the European Society of Hypertension (ESH). European Heart Journal, 2018. 39(33): p. 3021-3104.

2. Lepor, H., Medical treatment of benign prostatic hyperplasia. Rev Urol, 2011. 13(1): p. 20-33.

3. Oelke, M., et al., EAU guidelines on the treatment and follow-up of non-neurogenic male lower urinary tract symptoms including benign prostatic obstruction. Eur Urol, 2013. 64(1): p. 118-40.

4. Schwinn, D.A. and C.G. Roehrborn, Alpha1-adrenoceptor subtypes and lower urinary tract symptoms. Int J Urol, 2008. 15(3): p. 193-9.

5. Michel, M.C., The forefront for novel therapeutic agents based on the pathophysiology of lower urinary tract dysfunction: alpha-blockers in the treatment of male voiding dysfunction - how do they work and why do they differ in tolerability? J Pharmacol Sci, 2010. 112(2): p. 151-7.

6. Chow, C.K., et al., Prevalence, Awareness, Treatment, and Control of Hypertension in Rural and Urban Communities in High-, Middle-, and Low-Income Countries. JAMA, 2013. 310(9): p. 959-968.

7. Parsons, J.K., Benign Prostatic Hyperplasia and Male Lower Urinary Tract Symptoms: Epidemiology and Risk Factors. Curr Bladder Dysfunct Rep, 2010. 5(4): p. 212-218.

8. Kearney, P.M., et al., Global burden of hypertension: analysis of worldwide data. The Lancet, 2005. 365(9455): p. $217-223$. 
9. Parsons, J.K., et al., Obesity and benign prostatic hyperplasia: clinical connections, emerging etiological paradigms and future directions. J Urol, 2013. 189(1 Suppl): p. S102-6.

10. Patel, N.D. and J.K. Parsons, Epidemiology and etiology of benign prostatic hyperplasia and bladder outlet obstruction. Indian J Urol, 2014. 30(2): p. 1706.

11. Egan, K.B., The Epidemiology of Benign Prostatic Hyperplasia Associated with Lower Urinary Tract Symptoms: Prevalence and Incident Rates. Urol Clin North Am, 2016. 43(3): p. 289-97.

12. Rudner, X.L., et al., Subtype specific regulation of human vascular alpha(1)-adrenergic receptors by vessel bed and age. Circulation, 1999. 100(23): $\mathrm{p}$. 2336-43.

13. Michel, M.C. and W. Vrydag, a1-, a2-and $\beta$-adrenoceptors in the urinary bladder, urethra and prostate. British journal of pharmacology, 2006. 147(S2): p. S88-S119.

14. Michel, M.C., et al., Comparison of tamsulosin efficacy in subgroups of patients with lower urinary tract symptoms. Prostate Cancer Prostatic Dis, 1998. 1(6): p. 332-335.

15. Roehrborn, C.G., Three months' treatment with the alpha1-blocker alfuzosin does not affect total or transition zone volume of the prostate. Prostate Cancer Prostatic Dis, 2006. 9(2): p. 121-5.

16. Roehrborn, C.G., et al., The effects of dutasteride, tamsulosin and combination therapy on lower urinary tract symptoms in men with benign prostatic hyperplasia and prostatic enlargement: 2-year results from the CombAT study. J Urol, 2008. 179(2): p. 616-21; discussion 621.

17. Roehrborn, C.G., et al., The effects of combination therapy with dutasteride and tamsulosin on clinical outcomes in men with symptomatic benign prostatic hyperplasia: 4-year results from the CombAT study. Eur Urol, 2010. 57(1): p. 123-31.

18. Debruyne, F.M.J., Alpha blockers: are all created equal? Urology, 2000. 56(5, Supplement 1): p. $20-22$.

19. Mangoni, A.A. and S.H. Jackson, Age-related changes in pharmacokinetics and pharmacodynamics: basic principles and practical applications. Br J Clin Pharmacol, 2004. 57(1): p. 6-14.

20. Lavan, A.H. and P. Gallagher, Predicting risk of adverse drug reactions in older adults. Ther Adv Drug Saf, 2016. 7(1): p. 11-22.

21. van den Akker, M., F. Buntinx, and J.A. Knottnerus, Comorbidity or multimorbidity. European Journal of General Practice, 1996. 2(2): p. 65-70.

22. Jano, E. and R.R. Aparasu, Healthcare outcomes associated with beers' criteria: a systematic review. Ann Pharmacother, 2007. 41(3): p. 438-47.

23. Onder, G., et al., Adverse drug reactions as cause of hospital admissions: results from the Italian Group of Pharmacoepidemiology in the Elderly (GIFA). J Am Geriatr Soc, 2002. 50(12): p. 1962-8.

24. Davies, E.C., et al., Adverse drug reactions in hospital in-patients: a prospective analysis of 3695 patient-episodes. PLoS One, 2009. 4(2): p. e4439.

25. American Geriatrics Society 2019 Updated AGS Beers Criteria(R) for Potentially Inappropriate Medication Use in Older Adults. J Am Geriatr Soc, 2019. 67(4): p. 674-694.

26. Renom-Guiteras, A., G. Meyer, and P.A. Thurmann, The EU(7)-PIM list: a list of potentially inappropriate medications for older people consented by experts from seven European countries. Eur J Clin Pharmacol, 2015. 71(7): p. 861-75.

27. Holt, S., S. Schmiedl, and P.A. Thurmann, Potentially inappropriate medications in the elderly: the PRISCUS list. Dtsch Arztebl Int, 2010. 107(31-32): p. 543-51.

28. Mann, E., et al., Potentially inappropriate medication in geriatric patients: the Austrian consensus panel list. Wiener klinische Wochenschrift, 2012. 124(5): p. 160-169.

29. Laroche, M.L., J.P. Charmes, and L. Merle, Potentially inappropriate medications in the elderly: a French consensus panel list. Eur J Clin Pharmacol, 2007. 63(8): p. 725-31.

30. McLeod, P.J., et al., Defining inappropriate practices in prescribing for elderly people: a national consensus panel. Cmaj, 1997. 156(3): p. 385-91.

31. Higgins JPT, T.J., Chandler J, Cumpston M, Li T, Page MJ, Welch VA (editors), Cochrane Handbook for Systematic Reviews of Interventions version 6.0 (updated July 2019). 2019, Cochrane.

32. Review Manager 5.3. The Cochrane Collaboration 2019 [cited 2020 April 15]; Available from: revman.cochrane.org.

33. Sterne, J.A.C., et al., RoB 2: a revised tool for assessing risk of bias in randomised trials. Bmj, 2019. 366: p. I4898. 
34. Critical Appraisal Skills Programme. CASP Case Control Study Checklist 2018 [cited 2020 April 15]; Available from: https://casp-uk.net/wpcontent/uploads/2018/01/CASP-Case-Control-Study-Checklist-2018.pdf.

35. Critical Appraisal Skills Programme. CASP Cohort Study Checklist 2018 [cited 2020 April 15]; Available from: https://casp-uk.net/wpcontent/uploads/2018/01/CASP-Cohort-Study-Checklist_2018.pdf.

36. Shea, B.J., et al., AMSTAR 2: a critical appraisal tool for systematic reviews that include randomised or non-randomised studies of healthcare interventions, or both. Bmj, 2017. 358: p. j4008.

37. 2018 ESC/ESH Guidelines for the management of arterial hypertension. Rev Esp Cardiol (Engl Ed), 2019. $72(2):$ p. 160.

38. European Association, U., European Association of Urology Guidelines. 2020 Edition. Vol. presented at the EAU Annual Congress Amsterdam 2020. 2020, Arnhem, The Netherlands: European Association of Urology Guidelines Office.

39. Guyatt, G.H., et al., What is "quality of evidence" and why is it important to clinicians? BMJ, 2008. 336(7651): p. 995-998.

40. Guyatt, G.H., et al., Going from evidence to recommendations. Bmj, 2008. 336(7652): p. 1049-51.

41. Guyatt, G.H., et al., GRADE: an emerging consensus on rating quality of evidence and strength of recommendations. Bmj, 2008. 336(7650): p. 924-6.

42. Liberati, A., et al., The PRISMA statement for reporting systematic reviews and meta-analyses of studies that evaluate healthcare interventions: explanation and elaboration. Bmj, 2009. 339: p. b2700.

43. Diuretic versus alpha-blocker as first-step antihypertensive therapy: final results from the Antihypertensive and Lipid-Lowering Treatment to Prevent Heart Attack Trial (ALLHAT). Hypertension, 2003. 42(3): p. 239-46.

44. Gotoh, M., et al., Comparison of tamsulosin and naftopidil for efficacy and safety in the treatment of benign prostatic hyperplasia: a randomized controlled trial. BJU Int, 2005. 96(4): p. 581-6.

45. Nishino, Y., et al., Comparison of two alpha1-adrenoceptor antagonists, naftopidil and tamsulosin hydrochloride, in the treatment of lower urinary tract symptoms with benign prostatic hyperplasia: a randomized crossover study. BJU Int, 2006. 97(4): p. 747-51, discussion 751.

46. Oelke, M., et al., Treatment satisfaction with tadalafil or tamsulosin vs placebo in men with lower urinary tract symptoms (LUTS) suggestive of benign prostatic hyperplasia (BPH): results from a randomised, placebo-controlled study. BJU Int, 2014. 114(4): p. 568-75.

47. Roehrborn, C.G. and A.S. Group, Alfuzosin $10 \mathrm{mg}$ once daily prevents overall clinical progression of benign prostatic hyperplasia but not acute urinary retention: results of a 2-year placebo-controlled study. BJU International, 2006. 97(4): p. 734-741.

48. Yokoyama, T., et al., Effects of three types of alpha-1 adrenoceptor blocker on lower urinary tract symptoms and sexual function in males with benign prostatic hyperplasia. Int J Urol, 2011. 18(3): p. 225-30.

49. Chrischilles, E., et al., Initiation of nonselective alpha1-antagonist therapy and occurrence of hypotension-related adverse events among men with benign prostatic hyperplasia: a retrospective cohort study. Clin Ther, 2001. 23(5): p. 727-43.

50. Duan, Y., et al., Tamsulosin and the risk of dementia in older men with benign prostatic hyperplasia. Pharmacoepidemiol Drug Saf, 2018. 27(3): p. 340348.

51. Welk, B., et al., The risk of fall and fracture with the initiation of a prostate-selective alpha antagonist: a population based cohort study. Bmj, 2015. 351: $\mathrm{p}$. h5398.

52. Hall, G.C. and A.D. McMahon, Comparative study of modified release alpha-blocker exposure in elderly patients with fractures. Pharmacoepidemiol Drug Saf, 2007. 16(8): p. 901-7.

53. Testa, G., et al., Hypotensive Drugs and Syncope Due to Orthostatic Hypotension in Older Adults with Dementia (Syncope and Dementia Study). J Am Geriatr Soc, 2018. 66(8): p. 1532-1537.

54. Buzelin, J.M., et al., Clinical uroselectivity: evidence from patients treated with slow-release alfuzosin for symptomatic benign prostatic obstruction. Br J Urol, 1997. 79(6): p. 898-904; discussion 904-6.

55. Chapple, C.R., et al., Tamsulosin $0.4 \mathrm{mg}$ once daily: tolerability in older and younger patients with lower urinary tract symptoms suggestive of benign prostatic obstruction (symptomatic BPH). The European Tamsulosin Study Group. Eur Urol, 1997. 32(4): p. $462-70$.

56. Lowe, F.C., Safety assessment of terazosin in the treatment of patients with symptomatic benign prostatic hyperplasia: a combined analysis. Urology, 1994. 44(1): p. 46-51.

57. Jung, J.H., et al., Silodosin for the treatment of lower urinary tract symptoms in men with benign prostatic hyperplasia. Cochrane Database Syst Rev, 2017. 11: p. Cd012615. 
58. Hwang, E.C., et al., Naftopidil for the treatment of lower urinary tract symptoms compatible with benign prostatic hyperplasia. Cochrane Database Syst Rev, 2018. 10: p. Cd007360.

59. Yuan, J.Q., et al., Comparative Effectiveness and Safety of Monodrug Therapies for Lower Urinary Tract Symptoms Associated With Benign Prostatic Hyperplasia: A Network Meta-analysis. Medicine (Baltimore), 2015. 94(27): p. e974.

60. Fusco, F., et al., Alpha-1 adrenergic antagonists, 5-alpha reductase inhibitors, phosphodiesterase type 5 inhibitors, and phytotherapic compounds in men with lower urinary tract symptoms suggestive of benign prostatic obstruction: A systematic review and meta-analysis of urodynamic studies. Neurourol Urodyn, 2018. 37(6): p. 1865-1874.

61. Fusco, F., et al., a1-Blockers Improve Benign Prostatic Obstruction in Men with Lower Urinary Tract Symptoms: A Systematic Review and Meta-analysis of Urodynamic Studies. European Urology, 2016. 69(6): p. 1091-1101.

62. Nickel, J.C., S. Sander, and T.D. Moon, A meta-analysis of the vascular-related safety profile and efficacy of alpha-adrenergic blockers for symptoms related to benign prostatic hyperplasia. Int J Clin Pract, 2008. 62(10): p. 1547-59.

63. Djavan, B., et al., State of the art on the efficacy and tolerability of alpha1-adrenoceptor antagonists in patients with lower urinary tract symptoms suggestive of benign prostatic hyperplasia. Urology, 2004. 64(6): p. 1081-1088.

64. Chapman, N., et al., Effect of doxazosin gastrointestinal therapeutic system as third-line antihypertensive therapy on blood pressure and lipids in the Anglo-Scandinavian Cardiac Outcomes Trial. Circulation, 2008. 118(1): p. 42-8.

65. Wolak, T., et al., Doxazosin to treat hypertension: it's time to take it personally - a retrospective analysis of 19495 patients. Journal of Hypertension, 2014. 32(5): p. 1132-1137.

\section{Tables}

Table 1 Summary of study findings of included interventional studies

* Results calculated based on the figures provided in the original paper

Table 2 Summary of study findings of included observational studies 


\begin{tabular}{|c|c|c|c|c|c|c|}
\hline $\begin{array}{l}\text { Authors } \\
\text { (Year) }\end{array}$ & Drug vs. comparator & Outcome & $\begin{array}{l}\text { Relative Risk (RR)/Odds } \\
\text { Ratio (OR)/Hazard Ratio } \\
\text { (HR) }\end{array}$ & $\begin{array}{l}\text { Mean } \\
\text { difference } \\
(95 \% \mathrm{Cl})\end{array}$ & $\begin{array}{l}\text { Events (\%) or mean } \\
\text { score (SD) }\end{array}$ & $\begin{array}{l}\mathrm{p}- \\
\text { value }\end{array}$ \\
\hline \multirow[t]{4}{*}{$\begin{array}{l}\text { ALLHAT } \\
(2003)[43]\end{array}$} & $\begin{array}{l}\text { Doxazosin vs. } \\
\text { chlorthalidone }\end{array}$ & $\begin{array}{l}\text { Combined CVD } \\
<65 \mathrm{y}\end{array}$ & RR: 1.15 (1.04-1.27) & & & $<0.05$ \\
\hline & $\begin{array}{l}\text { Doxazosin vs. } \\
\text { chlorthalidone }\end{array}$ & $\begin{array}{l}\text { Combined CVD } \\
\geq 65 \mathrm{y}\end{array}$ & RR: 1.23 (1.14-1.32) & & & $<0.05$ \\
\hline & $\begin{array}{l}\text { Doxazosin vs. } \\
\text { chlorthalidone }\end{array}$ & $\begin{array}{l}\text { Heart failure } \\
<65 \text { y }\end{array}$ & RR: 1.76 (1.40-2.22) & & & $<0.05$ \\
\hline & $\begin{array}{l}\text { Doxazosin vs. } \\
\text { chlorthalidone }\end{array}$ & $\begin{array}{l}\text { Heart failure } \\
\geq 65 \mathrm{y}\end{array}$ & RR: 1.89 (1.65-2.17) & & & $<0.05$ \\
\hline \multirow{7}{*}{$\begin{array}{l}\text { Gotoh et al. } \\
(2005) \text { [44] }\end{array}$} & $\begin{array}{l}\text { Tamsulosin } 0.2 \mathrm{mg} \\
\text { intragroup }\end{array}$ & $\begin{array}{l}\text { Change in IPSS pre vs. post } \\
\text { administration }\end{array}$ & & $\begin{array}{l}-8.4(-10 \\
-6.8)\end{array}$ & & $<0.001$ \\
\hline & $\begin{array}{l}\text { Naftopidil } 50 \mathrm{mg} \\
\text { intragroup }\end{array}$ & $\begin{array}{l}\text { Change in IPSS pre vs. post } \\
\text { administration }\end{array}$ & & $\begin{array}{l}-5.9(-7.3 \\
-4.5)\end{array}$ & & $<0.001$ \\
\hline & $\begin{array}{l}\text { Tamsulosin } 0.2 \mathrm{mg} \text { vs. } \\
\text { naftopidil } 50 \mathrm{mg}\end{array}$ & $\begin{array}{l}\text { Change in IPSS pre vs. post } \\
\text { administration }\end{array}$ & & $\begin{array}{l}-8.4(-10 \\
-6.8) \text { vs. } \\
-5.9(-7.3 \\
-4.5)\end{array}$ & & 0.060 \\
\hline & $\begin{array}{l}\text { Tamsulosin } 0.2 \mathrm{mg} \\
\text { intragroup }\end{array}$ & $\begin{array}{l}\text { Change in QoL-score pre vs. } \\
\text { post administration }\end{array}$ & & $\begin{array}{l}-1.4(-1.7 \\
-1.1)\end{array}$ & & $<0.001$ \\
\hline & $\begin{array}{l}\text { Naftopidil } 50 \text { mg } \\
\text { intragroup }\end{array}$ & $\begin{array}{l}\text { Change in QoL-score pre vs. } \\
\text { post administration }\end{array}$ & & $\begin{array}{l}-1.3(-1.7 \\
-1.0)\end{array}$ & & $<0.001$ \\
\hline & $\begin{array}{l}\text { Tamsulosin } 0.2 \mathrm{mg} \text { vs. } \\
\text { naftopidil } 50 \mathrm{mg}\end{array}$ & $\begin{array}{l}\text { Change in QoL-score pre vs. } \\
\text { post administration }\end{array}$ & & $\begin{array}{l}-1.4(-1.7 \\
-1.1) \text { vs. } \\
-1.3(-1.7 \\
-1.0)\end{array}$ & & 0.801 \\
\hline & $\begin{array}{l}\text { Tamsulosin } 0.2 \mathrm{mg} \text { vs. } \\
\text { naftopidil } 50 \mathrm{mg}\end{array}$ & ADEs & & & $\begin{array}{l}9 / 95(9.5 \%) \text { vs. } \\
9 / 90(10 \%)\end{array}$ & 0.94 \\
\hline \multirow{8}{*}{$\begin{array}{l}\text { Nishino et } \\
\text { al. } \\
(2006)[45]\end{array}$} & $\begin{array}{l}\text { Tamsulosin } 0.2 \mathrm{mg} \\
\text { intragroup }\end{array}$ & $\begin{array}{l}\text { IPSS pre-vs. post- } \\
\text { administration }\end{array}$ & & & $\begin{array}{l}20.4(3.5) \text { vs. } \\
9.3(3.0)\end{array}$ & $<0.001$ \\
\hline & $\begin{array}{l}\text { Naftopidil } 50 \mathrm{mg} \\
\text { intragroup }\end{array}$ & $\begin{array}{l}\text { IPSS pre- vs. post- } \\
\text { administration }\end{array}$ & & & $\begin{array}{l}20.4(3.5) \text { vs. } \\
8.9(3.2)\end{array}$ & $<0.001$ \\
\hline & $\begin{array}{l}\text { Tamsulosin } 0.2 \mathrm{mg} \text { vs. } \\
\text { naftopidil } 50 \mathrm{mg}\end{array}$ & $\begin{array}{l}\text { Change in IPSS pre- to post- } \\
\text { administration between } \\
\text { substances }\end{array}$ & & & $\begin{array}{l}20.4(3.5) \text { to } \\
9.3(3.0) \text { vs. } \\
20.4(3.5) \text { to } \\
8.9(3.2)\end{array}$ & 0.265 \\
\hline & $\begin{array}{l}\text { Tamsulosin } 0.2 \mathrm{mg} \\
\text { intragroup }\end{array}$ & $\begin{array}{l}\text { QoL-score pre- vs. post- } \\
\text { administration }\end{array}$ & & & $\begin{array}{l}4.9(0.7) \text { vs. } \\
2.7(1.1)\end{array}$ & $<0.001$ \\
\hline & $\begin{array}{l}\text { Naftopidil } 50 \text { mg } \\
\text { intragroup }\end{array}$ & $\begin{array}{l}\text { QoL-score pre- vs. post- } \\
\text { administration }\end{array}$ & & & $\begin{array}{l}4.9(0.7) \text { vs. } \\
2.6(1.1)\end{array}$ & $<0.001$ \\
\hline & $\begin{array}{l}\text { Tamsulosin } 0.2 \mathrm{mg} \text { vs. } \\
\text { naftopidil } 50 \mathrm{mg}\end{array}$ & $\begin{array}{l}\text { Change in QoL-score pre- to } \\
\text { post-administration between } \\
\text { substances }\end{array}$ & & & $\begin{array}{l}4.9(0.7) \text { to } \\
2.7(1.1) \text { vs. } \\
4.9(0.7) \text { to } \\
2.6(1.1)\end{array}$ & 0.201 \\
\hline & $\begin{array}{l}\text { Naftopidil } 50 \mathrm{mg} \text { vs. } \\
\text { tamsulosin } 0.2 \mathrm{mg}\end{array}$ & ADEs & & & $\begin{array}{l}0 / 34(0 \%) \text { vs. } \\
0 / 34(0 \%)\end{array}$ & $>0.05$ \\
\hline & $\begin{array}{l}\text { Tamsulosin } 0.2 \mathrm{mg} \text { vs. } \\
\text { naftopidil } 50 \mathrm{mg}\end{array}$ & Withdrawals & & & $\begin{array}{l}0 / 34(0 \%) \text { vs. } \\
0 / 34(0 \%)\end{array}$ & $>0.05$ \\
\hline \multirow[t]{4}{*}{$\begin{array}{l}\text { Oelke et al. } \\
(2014) \text { [46] }\end{array}$} & $\begin{array}{l}\text { Tamsulosin } 0.4 \text { mg vs. } \\
\text { placebo }\end{array}$ & TSS-BPH $\leq 65$ y & & & $\begin{array}{l}28.8(16.9) \text { vs. } 31.2 \\
(17.3)\end{array}$ & 0.212 \\
\hline & $\begin{array}{l}\text { Tamsulosin } 0.4 \text { mg vs. } \\
\text { placebo }\end{array}$ & TSS-BPH >65 y & & & $\begin{array}{l}32.4(15.8) \text { vs. } 32.2 \\
(17.9)\end{array}$ & 0.759 \\
\hline & Tadalafil 5 mg vs. placebo & TSS-BPH $\leq 65$ y & & & $\begin{array}{l}25.2(17.8) \text { vs. } 31.2 \\
(17.3)\end{array}$ & 0.013 \\
\hline & Tadalafil 5 mg vs. placebo & TSS-BPH >65 y & & & $\begin{array}{l}29.0(17.6) \text { vs. } 32.2 \\
(17.9)\end{array}$ & 0.184 \\
\hline \multirow[t]{2}{*}{$\begin{array}{l}\text { Roehrborn } \\
(2006)[47]\end{array}$} & $\begin{array}{l}\text { Alfuzosin } 10 \mathrm{mg} \text { vs. } \\
\text { placebo }\end{array}$ & $\begin{array}{l}\text { Worsening of IPSS by } \geq 4 \text { within } \\
2 \text { years treatment } \geq 65 y\end{array}$ & RR: $0.84(0.62-1.15)^{\star}$ & & $\begin{array}{l}62 / 443(14 \%) \text { vs. } \\
72 / 433(16.6 \%)\end{array}$ & $>0.05$ \\
\hline & $\begin{array}{l}\text { Alfuzosin } 10 \mathrm{mg} \text { vs. } \\
\text { placebo }\end{array}$ & $\begin{array}{l}\text { Occurrence of AUR within } 2 \\
\text { years treatment } \geq 65 \mathrm{y}\end{array}$ & RR: $0.98(0.39-2.44)^{\star}$ & & $\begin{array}{l}9 / 443(2 \%) \text { vs. } \\
9 / 433(2,1 \%)\end{array}$ & $>0.05$ \\
\hline
\end{tabular}

Page 15/24 


\begin{tabular}{|c|c|c|c|c|}
\hline & $\begin{array}{l}\text { Alfuzosin } 10 \mathrm{mg} \text { vs. } \\
\text { placebo }\end{array}$ & $\begin{array}{l}\text { Need for BPH-related surgery } \\
\text { within } 2 \text { years treatment } \geq 65 \text { y }\end{array} \quad$ RR: $0.64(0.36-1.12)^{*}$ & $\begin{array}{l}19 / 443(4.3 \%) \text { vs. } \\
29 / 433(6.7 \%)\end{array}$ & $>0.05$ \\
\hline \multirow{11}{*}{$\begin{array}{l}\text { Yokoyama } \\
\text { et al. } \\
(2011)[48]\end{array}$} & Silodosin $8 \mathrm{mg}$ intragroup & $\begin{array}{l}\text { IPSS pre- vs. post- } \\
\text { administration }\end{array}$ & $\begin{array}{l}18.7(0.7) \text { vs. } \\
13.8(1.2)\end{array}$ & $<0.001$ \\
\hline & $\begin{array}{l}\text { Tamsulosin } 0.2 \mathrm{mg} \\
\text { intragroup }\end{array}$ & $\begin{array}{l}\text { IPSS pre- vs. post- } \\
\text { administration }\end{array}$ & $\begin{array}{l}18.0(1.1) \text { vs. } \\
10.7(1.4)\end{array}$ & $<0.001$ \\
\hline & $\begin{array}{l}\text { Naftopidil } 50 \mathrm{mg} \\
\text { intragroup }\end{array}$ & $\begin{array}{l}\text { IPSS pre- vs. post- } \\
\text { administration }\end{array}$ & $\begin{array}{l}17.4(0.8) \text { vs. } \\
11.3(1.1)\end{array}$ & $<0.001$ \\
\hline & $\begin{array}{l}\text { Silodosin } 8 \mathrm{mg} \text { vs. } \\
\text { tamsulosin } 0.2 \mathrm{mg} \text { vs. } \\
\text { naftopidil } 50 \mathrm{mg}\end{array}$ & $\begin{array}{l}\text { Change in IPSS pre- vs. post- } \\
\text { administration between } \\
\text { substances }\end{array}$ & $\begin{array}{l}18.7(0.7) \text { to } \\
13.8(1.2) \text { vs. } \\
18.0(1.1) \text { to } \\
10.7(1.4) \text { vs. } \\
17.4(0.8) \text { to } \\
11.3(1.1)\end{array}$ & $>0.05$ \\
\hline & Silodosin $8 \mathrm{mg}$ intragroup & $\begin{array}{l}\text { QoL-score pre- vs. post- } \\
\text { administration }\end{array}$ & $\begin{array}{l}4.5(0.1) \text { vs. } \\
3.4(0.2)\end{array}$ & $<0.001$ \\
\hline & $\begin{array}{l}\text { Tamsulosin } 0.2 \mathrm{mg} \\
\text { intragroup }\end{array}$ & $\begin{array}{l}\text { QoL-score pre- vs. post- } \\
\text { administration }\end{array}$ & $\begin{array}{l}4.5(0.1) \text { vs. } \\
2.7(0.3)\end{array}$ & $<0.001$ \\
\hline & $\begin{array}{l}\text { Naftopidil } 50 \mathrm{mg} \\
\text { intragroup }\end{array}$ & $\begin{array}{l}\text { QoL-score pre- vs. post- } \\
\text { administration }\end{array}$ & $\begin{array}{l}4.5(0.1) \text { vs. } \\
3.1(0.2)\end{array}$ & $<0.001$ \\
\hline & $\begin{array}{l}\text { Silodosin } 8 \mathrm{mg} \text { vs. } \\
\text { tamsulosin } 0.2 \mathrm{mg} \text { vs. } \\
\text { naftopidil } 50 \mathrm{mg}\end{array}$ & $\begin{array}{l}\text { Change in QoL-score pre- to } \\
\text { post- administration between } \\
\text { substances }\end{array}$ & $\begin{array}{l}4.5(0.1) \text { to } \\
3.4(0.2) \text { vs. } \\
4.5(0.1) \text { to } \\
2.7(0.3) \text { vs. } \\
4.5(0.1) \text { to } \\
3.1(0.2)\end{array}$ & $>0.05$ \\
\hline & $\begin{array}{l}\text { Silodosin } 8 \mathrm{mg} \text { vs. } \\
\text { tamsulosin } 0.2 \mathrm{mg} \text { vs. } \\
\text { naftopidil }\end{array}$ & Withdrawals due to ADEs & $\begin{array}{l}4 / 41(9,8 \%) \text { vs. } 1 / 39 \\
(2,6 \%) \text { vs. } 1 / 42 \\
(2,4 \%)\end{array}$ & \\
\hline & $\begin{array}{l}\text { Silodosin } 8 \mathrm{mg} \text { vs. } \\
\text { tamsulosin0.2 mg vs. } \\
\text { naftopidil }\end{array}$ & $\begin{array}{l}\text { Abnormal ejaculation after } 4 \text { - } \\
\text { week treatment }\end{array}$ & $\begin{array}{l}10 / 11(90,9 \%) \text { vs. } \\
1 / 12(8,3 \%) \text { vs. } 1 / 15 \\
(6,7 \%)\end{array}$ & \\
\hline & $\begin{array}{l}\text { Silodosin } 8 \mathrm{mg} \text { vs. } \\
\text { tamsulosin } 0.2 \mathrm{mg} \text { vs. } \\
\text { naftopidil }\end{array}$ & $\begin{array}{l}\text { Abnormal ejaculation after } 12- \\
\text { week treatment }\end{array}$ & $\begin{array}{l}8 / 10(80 \%) \text { vs. } 1 / 5 \\
(20 \%) \text { vs. } 1 / 14 \\
(7,1 \%)\end{array}$ & \\
\hline
\end{tabular}




\begin{tabular}{|c|c|c|c|c|c|c|}
\hline $\begin{array}{l}\text { Authors } \\
\text { (Year) }\end{array}$ & Drug vs. comparator & Outcome & $\begin{array}{l}\text { Relative Risk } \\
\text { (RR)/Odds Ratio } \\
\text { (OR)/Hazard Ratio } \\
\text { (HR) }\end{array}$ & $\begin{array}{l}\text { Mean } \\
\text { difference } \\
(95 \% \mathrm{Cl})\end{array}$ & $\begin{array}{l}\text { Events (\%) or mean } \\
\text { score (SD) }\end{array}$ & $\begin{array}{l}\mathrm{p}- \\
\text { value }\end{array}$ \\
\hline \multicolumn{7}{|c|}{ Retrospective Cohort Studies: } \\
\hline \multirow{24}{*}{$\begin{array}{l}\text { Chrischilles et } \\
\text { al. (2001) [49] }\end{array}$} & \multirow{3}{*}{$\begin{array}{l}\text { a1-blocker treatment vs. no a1- } \\
\text { blocker treatment }\end{array}$} & \multirow{2}{*}{$\begin{array}{l}\text { Compare no. of } \\
\text { ADEs } / 10,000 \text { person- } \\
\text { days }\end{array}$} & & & 2.82 to 4.64 vs. & \multirow[t]{3}{*}{0.001} \\
\hline & & & & & 3.62 to 3.60 & \\
\hline & & $\begin{array}{l}4 \text { months pre- to } 4 \\
\text { months post initiation }\end{array}$ & & & & \\
\hline & \multirow{3}{*}{$\begin{array}{l}\text { a1-blocker treatment vs. no a1- } \\
\text { blocker treatment }\end{array}$} & \multirow{2}{*}{$\begin{array}{l}\text { Compare no. of } \\
\text { ADEs/10,000 person- } \\
\text { days }\end{array}$} & & & 2.99 to 5.03 vs. & \multirow[t]{3}{*}{$<0.001$} \\
\hline & & & & & 3.88 to 3.56 & \\
\hline & & $\begin{array}{l}3 \text { months pre- to } 3 \\
\text { months post initiation }\end{array}$ & & & & \\
\hline & \multirow{3}{*}{$\begin{array}{l}\text { a1-blocker treatment vs. no a1- } \\
\text { blocker treatment }\end{array}$} & \multirow{2}{*}{$\begin{array}{l}\text { Compare no. of } \\
\text { ADEs } / 10,000 \text { person- } \\
\text { days }\end{array}$} & & & 3.53 to 5.89 vs. & \multirow[t]{3}{*}{$<0.001$} \\
\hline & & & & & 3.89 to 3.72 & \\
\hline & & $\begin{array}{l}2 \text { months pre- to } 2 \\
\text { months post initiation }\end{array}$ & & & & \\
\hline & \multirow{3}{*}{$\begin{array}{l}\text { a1-blocker treatment vs. no a1- } \\
\text { blocker treatment }\end{array}$} & \multirow{2}{*}{$\begin{array}{l}\text { Compare no. of } \\
\text { ADEs/10,000 person- } \\
\text { days }\end{array}$} & & & 4.72 to 7.07 vs. & \multirow[t]{3}{*}{0.001} \\
\hline & & & & & 4.04 to 3.69 & \\
\hline & & $\begin{array}{l}1 \text { month pre- to } 1 \text { month } \\
\text { post initiation }\end{array}$ & & & & \\
\hline & \multirow{3}{*}{$\begin{array}{l}\text { Concomitant antihypertensives: } \\
\text { a1-blocker treatment vs. no a1- } \\
\text { blocker treatment }\end{array}$} & \multirow{2}{*}{$\begin{array}{l}\text { Compare no. of } \\
\text { ADEs/10,000 person- } \\
\text { days }\end{array}$} & & & 4.21 to $5.15 \mathrm{vs}$. & \multirow[t]{3}{*}{$<0.006$} \\
\hline & & & & & 3.10 to 3.79 & \\
\hline & & $\begin{array}{l}4 \text { months pre- to } 4 \\
\text { months post initiation }\end{array}$ & & & & \\
\hline & \multirow{3}{*}{$\begin{array}{l}\text { Concomitant antihypertensives: } \\
\text { a1-blocker treatment vs. no a1- } \\
\text { blocker treatment }\end{array}$} & \multirow{2}{*}{$\begin{array}{l}\text { Compare no. of } \\
\text { ADEs/10,000 person- } \\
\text { days }\end{array}$} & & & 4.77 to 5.63 vs. & \multirow[t]{3}{*}{0.003} \\
\hline & & & & & 3.10 to 3.67 & \\
\hline & & $\begin{array}{l}3 \text { months pre- to } 3 \\
\text { months post initiation }\end{array}$ & & & & \\
\hline & \multirow{3}{*}{$\begin{array}{l}\text { Concomitant antihypertensives: } \\
\text { a1-blocker treatment vs. no a1- } \\
\text { blocker treatment }\end{array}$} & \multirow{2}{*}{$\begin{array}{l}\text { Compare no. of } \\
\text { ADEs/10,000 person- } \\
\text { days }\end{array}$} & & & 5.87 to 6.60 vs. & \multirow[t]{3}{*}{0.511} \\
\hline & & & & & 3.62 to 4.07 & \\
\hline & & $\begin{array}{l}2 \text { months pre- to } 2 \\
\text { months post initiation }\end{array}$ & & & & \\
\hline & \multirow{3}{*}{$\begin{array}{l}\text { Concomitant antihypertensives: } \\
\text { a1-blocker treatment vs. no a1- } \\
\text { blocker treatment }\end{array}$} & \multirow{2}{*}{$\begin{array}{l}\text { Compare no. of } \\
\text { ADEs/10,000 person- } \\
\text { days }\end{array}$} & & & 5.50 to 6.60 vs. & \multirow[t]{3}{*}{0.442} \\
\hline & & & & & 3.33 to 4.00 & \\
\hline & & $\begin{array}{l}1 \text { month pre- to } 1 \text { month } \\
\text { post initiation }\end{array}$ & & & & \\
\hline \multirow[t]{6}{*}{$\begin{array}{l}\text { Duan et al. } \\
\text { (2018) [50] }\end{array}$} & $\begin{array}{l}\text { Tamsulosin vs. no BPH } \\
\text { medication }\end{array}$ & $\begin{array}{l}\text { Incidence of } \\
\text { dementia/1,000 person- } \\
\text { years }\end{array}$ & HR: $1.17(1.14-1.21)$ & & 31.3 vs. 25.9 & $<0.001$ \\
\hline & Tamsulosin vs. doxazosin & $\begin{array}{l}\text { Incidence of } \\
\text { dementia/1,000 person- } \\
\text { years }\end{array}$ & HR: $1.20(1.12-1.28)$ & & 32.7 vs. 27.5 & $<0.001$ \\
\hline & Tamsulosin vs. terazosin & $\begin{array}{l}\text { Incidence of } \\
\text { dementia/1,000 person- } \\
\text { years }\end{array}$ & HR: 1.11 (1.04-1.19) & & 37.1 vs. 32.7 & 0.002 \\
\hline & Tamsulosin vs. alfuzosin & $\begin{array}{l}\text { Incidence of } \\
\text { dementia/1,000 person- } \\
\text { years }\end{array}$ & HR: 1.12 (1.03-1.22) & & 30.4 vs. 28.4 & 0.010 \\
\hline & Tamsulosin vs. dutasteride & $\begin{array}{l}\text { Incidence of } \\
\text { dementia/1,000 person- } \\
\text { years }\end{array}$ & HR: 1.26 (1.19-1.34) & & 32.7 vs. 26.5 & $<0.001$ \\
\hline & Tamsulosin vs. finasteride & $\begin{array}{l}\text { Incidence of } \\
\text { dementia/1,000 person- } \\
\text { years }\end{array}$ & HR: 1.13 (1.07-1.19) & & 36.9 vs. 32.8 & $<0.001$ \\
\hline Welk et al. & a1-blocker use vs. no use & Falls & OR: 1.14 (1.07-1.21) & & $\begin{array}{l}2,129(1.45 \%) \text { vs. } \\
1,881(1.28 \%)\end{array}$ & $<0.05$ \\
\hline
\end{tabular}

Page $17 / 24$ 


\begin{tabular}{|c|c|c|c|c|}
\hline a1-blocker use vs. no use & Fracture & OR: $1.16(1.04-1.29)$ & $\begin{array}{l}699(0.48 \%) \text { vs. } \\
605(0.41 \%)\end{array}$ & $<0.05$ \\
\hline a1-blocker use vs. no use & $\begin{array}{l}\text { Major osteoporotic } \\
\text { fracture }\end{array}$ & OR: 1.05 (0.89-1.23) & $\begin{array}{l}312(0.21 \%) \text { vs. } 298 \\
(0.20 \%)\end{array}$ & $>0.05$ \\
\hline a1-blocker use vs. no use & Hip fracture & OR: 0.98 (0.78-1.21) & $\begin{array}{l}159(0.11 \%) \text { vs. } 163 \\
(0.11 \%)\end{array}$ & $>0.05$ \\
\hline a1-blocker use vs. no use & Hypotension & OR: $1.80(1.59-2.03)$ & $\begin{array}{l}706(0.48 \%) \text { vs. } 394 \\
(0.27 \%)\end{array}$ & $<0.05$ \\
\hline a1-blocker use vs. no use & Head trauma & OR: 1.15 (1.04-1.27) & $\begin{array}{l}888(0.60 \%) \text { vs. } 773 \\
(0.53 \%)\end{array}$ & $<0.05$ \\
\hline a1-blocker use vs. no use & Falls in age group $<75 y$ & OR: 1.17 (1.04-1.31) & $\begin{array}{l}603(0.84 \%) \text { vs. } 515 \\
(0.71 \%)\end{array}$ & $<0.05$ \\
\hline a1-blocker use vs. no use & $\begin{array}{l}\text { Falls in age group } \geq 75 \\
y\end{array}$ & OR: $1.12(1.04-1.21)$ & $\begin{array}{l}1,526(2.04 \%) \text { vs. } \\
1,366(1.82 \%)\end{array}$ & $<0.05$ \\
\hline $\begin{array}{l}\text { Comparison a1-blocker use vs. no } \\
\text { use between age groups }\end{array}$ & $\begin{array}{l}\text { Falls }<75 \text { y } \\
\text { vs. } \\
\text { Falls } \geq 75 \text { y }\end{array}$ & & $\begin{array}{l}603(0.84 \%) \text { vs. } 515 \\
(0.71 \%) \text { vs. } 1,526 \\
(2.04 \%) \text { vs. } 1,366 \\
(1.82 \%)\end{array}$ & 0.52 \\
\hline Tamsulosin use vs. no use & Falls & OR: $1.12(1.04-1.19)$ & $\begin{array}{l}1,810(1.47 \%) \text { vs. } 1,625 \\
(1.32 \%)\end{array}$ & $<0.05$ \\
\hline Alfuzosin use vs. no use & Falls & OR: $1.24(1.04-1.48)$ & $\begin{array}{l}279(1.34 \%) \text { vs. } 226 \\
(1.09 \%)\end{array}$ & $<0.05$ \\
\hline Silodosin use vs. no use & Falls & OR: $1.35(0.83-2.18)$ & $\begin{array}{l}40(1.47 \%) \text { vs. } \\
30(1.10 \%)\end{array}$ & $>0.05$ \\
\hline $\begin{array}{l}\text { Comparison of fall-rates } \\
\text { (substance vs. no substance) } \\
\text { between substances }\end{array}$ & $\begin{array}{l}\text { Falls tamsulosin use vs. } \\
\text { no use } \\
\text { vs. } \\
\text { falls alfuzosin use vs. } \\
\text { no use } \\
\text { vs. } \\
\text { falls silodosin use vs. } \\
\text { no use }\end{array}$ & $\begin{array}{l}\text { OR: } \\
1.12(1.04-1.19) \text { vs. } \\
1.24(1.04-1.48) \text { vs. } \\
1.35(0.83-2.18)\end{array}$ & & 0.44 \\
\hline Tamsulosin 0.4 mg vs. no use & Falls & OR: 1.09 (1.02-1.17) & $\begin{array}{l}1,622(1.42 \%) \text { vs. } 1,488 \\
(1.31 \%)\end{array}$ & $<0.05$ \\
\hline Tamsulosin $0.8 \mathrm{mg}$ vs. no use & Falls & OR: $1.21(0.91-1.62)$ & $\begin{array}{l}105(1.55 \%) \text { vs. } \\
87(1.28 \%)\end{array}$ & $>0.05$ \\
\hline $\begin{array}{l}\text { Comparison of fall-rates } \\
\text { (substance vs. no substance) } \\
\text { according to drug administration }\end{array}$ & $\begin{array}{l}\text { Falls tamsulosin } 0.4 \mathrm{mg} \\
\text { vs. no use } \\
\text { vs. } \\
\text { Falls tamsulosin } 0.8 \mathrm{mg} \\
\text { vs. no use }\end{array}$ & $\begin{array}{l}\text { OR: } 1.09(1.02-1.17) \\
\text { vs. } \\
1.21(0.91-1.62)\end{array}$ & & 0.49 \\
\hline
\end{tabular}

\section{Case-control studies:}

\begin{tabular}{|c|c|c|c|c|c|}
\hline \multirow[t]{10}{*}{$\begin{array}{l}\text { Hall and } \\
\text { McMahon } \\
(2007) \text { [52] }\end{array}$} & \multirow[t]{2}{*}{ Fractures vs. no fractures total } & \multirow[t]{2}{*}{ Current doxazosin use } & OR: $0.82(0.63-1.08)$ & $\begin{array}{l}66(1.01 \%) \text { vs. } \\
311(1.17 \%)\end{array}$ & \multirow[t]{2}{*}{$>0.05$} \\
\hline & & & $\begin{array}{l}\text { Adj. OR: } 0.90 \text { (0.68- } \\
1.19)\end{array}$ & & \\
\hline & \multirow[t]{2}{*}{ Fractures vs. no fractures } & \multirow[t]{2}{*}{$\begin{array}{l}\text { Doxazosin treatment } \\
\text { started within } 28 \text { days }\end{array}$} & \multirow[t]{2}{*}{ OR: 0.57 (0.17-1.92) } & & \multirow[t]{2}{*}{$>0.05$} \\
\hline & & & & $20(0.08 \%)$ & \\
\hline & \multirow[t]{2}{*}{ Fractures vs. no fractures } & \multirow{2}{*}{$\begin{array}{l}\text { Doxazosin treatment } \\
\text { started within } 84 \text { days }\end{array}$} & \multirow[t]{2}{*}{ OR: $0.48(0.23-1.01)$} & $8(0.12 \%)$ vs. & \multirow[t]{2}{*}{$>0.05$} \\
\hline & & & & $65(0.25 \%)$ & \\
\hline & \multirow{2}{*}{$\begin{array}{l}\text { Fractures vs. no fractures male } \\
\leq 75 a\end{array}$} & \multirow[t]{2}{*}{ Current doxazosin use } & \multirow[t]{2}{*}{ OR: $0.84(0.39-1.78)$} & $9(1.17 \%)$ vs. & \multirow[t]{2}{*}{$>0.05$} \\
\hline & & & & $39(1.19 \%)$ & \\
\hline & \multirow{2}{*}{$\begin{array}{l}\text { Fractures vs. no fractures female } \\
\leq 75 a\end{array}$} & \multirow[t]{2}{*}{ Current doxazosin use } & \multirow[t]{2}{*}{ OR: 1.08 (0.68-1.72) } & $25(0.97 \%)$ vs. & \multirow[t]{2}{*}{$>0.05$} \\
\hline & & & & $99(0.95 \%)$ & \\
\hline
\end{tabular}




\begin{tabular}{|c|c|c|c|c|c|}
\hline & $\begin{array}{l}\text { Fractures vs. no fractures male } \\
>75 a\end{array}$ & Current doxazosin use & OR: $0.61(0.20-1.83)$ & $\begin{array}{l}4(0.92 \%) \\
20(1.08 \%) \text { vs. }\end{array}$ & $>0.05$ \\
\hline & $\begin{array}{l}\text { Fractures vs. no fractures female } \\
>75 a\end{array}$ & Current doxazosin use & OR: $0.73(0.48-1.10)$ & $\begin{array}{l}28(1.01 \%) \text { vs. } \\
153(1.39 \%)\end{array}$ & $>0.05$ \\
\hline & Fractures vs. no fractures total & $\begin{array}{l}\text { Any previous doxazosin } \\
\text { use }\end{array}$ & OR: $0.84(0.67-1.04)$ & $\begin{array}{l}99(1.51 \%) \text { vs. } \\
468(1.77 \%)\end{array}$ & $>0.05$ \\
\hline & & & $\begin{array}{l}\text { Adj. OR: } 0.92(0.69- \\
1.23)\end{array}$ & & \\
\hline & $\begin{array}{l}\text { Fractures vs. no fractures male } \\
\leq 75 a\end{array}$ & $\begin{array}{l}\text { Any previous doxazosin } \\
\text { use }\end{array}$ & OR: $0.94(0.50-1.75)$ & $\begin{array}{l}13(1.68 \%) \text { vs. } \\
56(1.71 \%)\end{array}$ & $>0.05$ \\
\hline & $\begin{array}{l}\text { Fractures vs. no fractures female } \\
\leq 75 a\end{array}$ & $\begin{array}{l}\text { Any previous doxazosin } \\
\text { use }\end{array}$ & OR: 0.95 (0.65-1.38) & $\begin{array}{l}37(1.44 \%) \text { vs. } \\
163(1.57 \%)\end{array}$ & $>0.05$ \\
\hline & & & $\begin{array}{l}\text { Adj. OR: } 1.00(0.67- \\
1.48)\end{array}$ & & \\
\hline & $\begin{array}{l}\text { Fractures vs. no fractures male } \\
>75 a\end{array}$ & $\begin{array}{l}\text { Any previous doxazosin } \\
\text { use }\end{array}$ & OR: $0.95(0.42-2.14)$ & $\begin{array}{l}8(1.83 \%) \text { vs. } \\
28(1.51 \%)\end{array}$ & $>0.05$ \\
\hline & $\begin{array}{l}\text { Fractures vs. no fractures female } \\
>75 a\end{array}$ & $\begin{array}{l}\text { Any previous doxazosin } \\
\text { use }\end{array}$ & OR: $0.75(0.53-1.05)$ & $\begin{array}{l}41(1.48 \%) \text { vs. } \\
221(2.01 \%)\end{array}$ & $>0.05$ \\
\hline & & & $\begin{array}{l}\text { Adj. OR: } 0.83 \text { (0.58- } \\
1.17)\end{array}$ & & \\
\hline & $\begin{array}{l}\text { Fractures vs. no fractures (no } \\
\text { current exposure to doxazosin) }\end{array}$ & $\begin{array}{l}\text { Current exposure to } \\
\text { alpha-1 antagonist } \\
\text { other than doxazosin }\end{array}$ & $\begin{array}{l}\text { OR: } 0.89 \text { (0.71-1.12) } \\
\text { Adj. OR: } 0.93 \text { (0.73- } \\
1.18)\end{array}$ & $\begin{array}{l}94(1.44 \%) \text { vs. } \\
446(1.68 \%)\end{array}$ & $>0.05$ \\
\hline & $\begin{array}{l}\text { Fractures vs. no fractures (no } \\
\text { current exposure to doxazosin) }\end{array}$ & $\begin{array}{l}\text { Treatment with other } \\
\text { alpha1-antagonist } \\
\text { started within } 28 \text { days }\end{array}$ & OR: $1.42(0.65-3.07)$ & $\begin{array}{l}9(0.14 \%) \text { vs. } \\
28(0.11 \%)\end{array}$ & $>0.05$ \\
\hline & $\begin{array}{l}\text { Fractures vs. no fractures (no } \\
\text { current exposure to doxazosin) }\end{array}$ & $\begin{array}{l}\text { Treatment with other } \\
\text { alpha1-antagonist } \\
\text { started within } 84 \text { days }\end{array}$ & OR: $1.46(0.88-2.42)$ & $\begin{array}{l}21(0.32 \%) \text { vs. } \\
66(0.25 \%)\end{array}$ & $>0.05$ \\
\hline $\begin{array}{l}\text { Testa et al. } \\
(2018) \text { [53] }\end{array}$ & $\begin{array}{l}\text { Syncope due to orthostatic } \\
\text { hypotension }(\mathrm{OH}) \text { vs. non-OH } \\
\text { syncope }\end{array}$ & a1-blocker use & RR: 1.67 (1.00-2.85) & $\begin{array}{l}28 / 170(16.5 \%) \text { vs. } \\
18 / 184(9.8 \%)\end{array}$ & 0.043 \\
\hline & & & $\begin{array}{l}\text { Adj. for age and sex: } \\
\text { RR: } 1.48(0.84-2.60)\end{array}$ & & \\
\hline & $\begin{array}{l}\text { Syncope due to orthostatic } \\
\text { hypotension }(\mathrm{OH}) \text { vs. non-OH } \\
\text { syncope }\end{array}$ & a1-blocker + diuretic & RR: 1.70 (1.04-2.78) & $\begin{array}{l}14 / 170(8.2 \%) \text { vs. } \\
6 / 184(3.3 \%)\end{array}$ & 0.036 \\
\hline & & & $\begin{array}{l}\text { Adj. for age and sex: } \\
\text { RR: } 1.83(0.85-3.96)\end{array}$ & & \\
\hline
\end{tabular}

Table 3 Summary of study findings of included meta-analyses 


\begin{tabular}{|c|c|c|c|c|c|c|}
\hline $\begin{array}{l}\text { Authors } \\
\text { (Year) }\end{array}$ & Drug vs. comparator & Outcome & $\begin{array}{l}\text { Relative Risk (RR)/Odds } \\
\text { Ratio (OR)/Hazard Ratio } \\
\text { (HR) }\end{array}$ & $\begin{array}{l}\text { Mean } \\
\text { difference } \\
(95 \% \mathrm{Cl})\end{array}$ & $\begin{array}{l}\text { Events (\%) or } \\
\text { mean score } \\
\text { (SD) }\end{array}$ & $\begin{array}{l}\mathrm{p}- \\
\text { value }\end{array}$ \\
\hline \multirow{4}{*}{$\begin{array}{l}\text { Buzelin et } \\
\text { al. } \\
\text { (1997) [54] }\end{array}$} & \multirow[t]{2}{*}{ Alfuzosin vs. placebo } & \multirow[t]{2}{*}{ ADEs $\geq 65$ y } & & & $\begin{array}{l}12 / 149(8.1 \%) \\
\text { vs. }\end{array}$ & $>0.05$ \\
\hline & & & & & $12 / 153(7.8 \%)$ & \\
\hline & \multirow[t]{2}{*}{ Alfuzosin vs. placebo } & \multirow[t]{2}{*}{ ADEs related to vasodilation $\geq 65 y$} & & & $\begin{array}{l}2 / 149(1.3 \%) \\
\text { vs. }\end{array}$ & $>0.05$ \\
\hline & & & & & 2/153 (1.3\%) & \\
\hline \multirow[t]{20}{*}{$\begin{array}{l}\text { Lowe } \\
\text { (1994) [56] }\end{array}$} & \multirow[t]{10}{*}{$\begin{array}{l}\text { Terazosin vs. placebo in } \\
\text { the age group } 65 y-74 \\
y\end{array}$} & \multicolumn{3}{|l|}{ Dizziness } & $\begin{array}{l}25 / 235(9.8 \%) \\
\text { Vs. } \\
7 / 143(4.9 \%)\end{array}$ & $>0.05$ \\
\hline & & \multicolumn{3}{|l|}{ Asthenia } & $\begin{array}{l}16 / 235(6.8 \%) \\
\text { vs. } 1 / 143 \\
(0.7 \%)\end{array}$ & $<0.05$ \\
\hline & & \multicolumn{3}{|l|}{ Headache } & $\begin{array}{l}17 / 235(6.8 \%) \\
\text { vs. } 5 / 143 \\
(3.5 \%)\end{array}$ & $>0.05$ \\
\hline & & \multicolumn{3}{|l|}{ Postural symptoms } & $\begin{array}{l}15 / 235(6.0 \%) \\
\text { vs. } 2 / 143 \\
(1.4 \%)\end{array}$ & $<0.05$ \\
\hline & & \multicolumn{3}{|l|}{ Somnolence } & $\begin{array}{l}9 / 235(3.8 \%) \\
\text { vs. } 4 / 143 \\
(2.8 \%)\end{array}$ & $>0.05$ \\
\hline & & \multicolumn{3}{|l|}{ Nasal congestion } & $\begin{array}{l}5 / 235(2.1 \%) \\
\text { vs. } 0 / 143 \\
(0.0 \%)\end{array}$ & $>0.05$ \\
\hline & & \multicolumn{3}{|l|}{ Nausea } & $\begin{array}{l}4 / 235(1.7 \%) \\
\text { vs. } 1 / 143 \\
(0.7 \%)\end{array}$ & $>0.05$ \\
\hline & & \multicolumn{3}{|l|}{ Impotence } & $\begin{array}{l}4 / 235(1.7 \%) \\
\text { vs. } 1 / 143 \\
(0.7 \%)\end{array}$ & $>0.05$ \\
\hline & & \multicolumn{3}{|l|}{ Blurred vision } & $\begin{array}{l}6 / 235(2.6 \%) \\
\text { vs. } 0 / 143 \\
(0.0 \%)\end{array}$ & $<0.05$ \\
\hline & & \multicolumn{3}{|l|}{ Syncope } & $\begin{array}{l}3 / 235(1.3 \%) \\
\text { vs. } 0 / 143 \\
(0.0 \%)\end{array}$ & $>0.05$ \\
\hline & \multirow[t]{10}{*}{$\begin{array}{l}\text { Terazosin vs. placebo in } \\
\text { the age group }>74 \mathrm{y}\end{array}$} & \multicolumn{3}{|l|}{ Dizziness } & $\begin{array}{l}6 / 50(12 \%) \text { vs. } \\
0 / 19(0 \%)\end{array}$ & $<0.05$ \\
\hline & & \multicolumn{3}{|l|}{ Asthenia } & $\begin{array}{l}2 / 50(4.0 \%) \text { vs. } \\
1 / 19(5.3 \%)\end{array}$ & $>0.05$ \\
\hline & & \multicolumn{3}{|l|}{ Headache } & $\begin{array}{l}0 / 50(0.0 \%) \text { vs. } \\
1 / 19(5.3 \%)\end{array}$ & $>0.05$ \\
\hline & & \multicolumn{3}{|l|}{ Postural symptoms } & $\begin{array}{l}2 / 50(4.0 \%) \text { vs. } \\
0 / 19(0.0 \%)\end{array}$ & $>0.05$ \\
\hline & & \multicolumn{3}{|l|}{ Somnolence } & $\begin{array}{l}2 / 50(4.0 \%) \text { vs. } \\
1 / 19(5.3 \%)\end{array}$ & $>0.05$ \\
\hline & & \multicolumn{3}{|l|}{ Nasal congestion } & $\begin{array}{l}1 / 50(2.0 \%) \text { vs. } \\
0 / 19(0.0 \%)\end{array}$ & $>0.05$ \\
\hline & & \multicolumn{3}{|l|}{ Nausea } & $\begin{array}{l}0 / 50(0.0 \%) \text { vs. } \\
1 / 19(5.3 \%)\end{array}$ & $>0.05$ \\
\hline & & \multicolumn{3}{|l|}{ Impotence } & $\begin{array}{l}0 / 50(0.0 \%) \text { vs. } \\
0 / 19(0.0 \%)\end{array}$ & $>0.05$ \\
\hline & & \multicolumn{3}{|l|}{ Blurred vision } & $\begin{array}{l}0 / 50(0.0 \%) \text { vs. } \\
1 / 19(5.3 \%)\end{array}$ & $>0.05$ \\
\hline & & \multicolumn{3}{|l|}{ Syncope } & $\begin{array}{l}0 / 50(0.0 \%) \text { vs. } \\
0 / 19(0.0 \%)\end{array}$ & $>0.05$ \\
\hline $\begin{array}{l}\text { Chapple et } \\
\text { al. }\end{array}$ & $\begin{array}{l}\text { Tamsulosin vs. placebo } \\
\text { in the age group } \geq 65 \mathrm{y}\end{array}$ & \multirow{2}{*}{\multicolumn{3}{|c|}{ Any adverse event }} & $\begin{array}{l}\text { 70/191 (37\%) } \\
\text { vs. }\end{array}$ & 0.330 \\
\hline (1997) [55] & & & & & $31 / 100$ (31\%) & \\
\hline
\end{tabular}




\begin{tabular}{|c|c|c|}
\hline Drug related adverse event ${ }^{1}$ & $\begin{array}{l}23 / 191(12 \%) \\
\text { vs. } \\
9 / 100(9 \%)\end{array}$ & 0.459 \\
\hline Discontinued due to adverse events & $\begin{array}{l}7 / 191(3.7 \%) \\
\text { vs. } \\
4 / 100(4 \%)\end{array}$ & 1.000 \\
\hline Serious adverse events & $\begin{array}{l}5 / 191(2.6 \%) \\
\text { Vs. } \\
4 / 100(4 \%)\end{array}$ & 0.499 \\
\hline $\begin{array}{l}\text { Adverse events possibly associated } \\
\text { with vasodilation }{ }^{2}\end{array}$ & $\begin{array}{l}8 / 191(4.2 \%) \\
\text { vs. } \\
6 / 100(6 \%)\end{array}$ & 0.523 \\
\hline $\begin{array}{l}\text { Adverse events possibly associated } \\
\text { with vasodilation }{ }^{2} \text { and drug related }\end{array}$ & $\begin{array}{l}7 / 191(3.7 \%) \\
\text { Vs. } \\
3 / 100(3 \%)\end{array}$ & 0.767 \\
\hline Abnormal ejaculation & $\begin{array}{l}5 / 191(2.6 \%) \\
\text { vs. } \\
1 / 100(1.0 \%)\end{array}$ & 0.668 \\
\hline Dizziness & $\begin{array}{l}5 / 191(2.6 \%) \\
\text { vs. } \\
3 / 100(3.0 \%)\end{array}$ & 1.000 \\
\hline Flu syndrome & $\begin{array}{l}5 / 191(2.6 \%) \\
\text { vs. } \\
3 / 100(3.0 \%)\end{array}$ & 1.000 \\
\hline Infection & $\begin{array}{l}4 / 191(2.1 \%) \\
\text { vs. } \\
1 / 100(1.0 \%)\end{array}$ & 0.663 \\
\hline
\end{tabular}

${ }^{1}$ Decision taken by the investigator: possibly or probably drug related.

${ }^{2}$ Includes dizziness, headache, tachycardia, palpitation, postural hypotension and syncope.

Table 4 Critical quality appraisal for included meta-analyses according to AMSTAR 2 [35]

\begin{tabular}{|c|c|c|c|c|c|c|c|c|c|c|}
\hline $\begin{array}{l}\text { Authors } \\
\text { (Year) }\end{array}$ & $\begin{array}{l}\text { PICO } \\
\text { scheme } \\
\text { used? }\end{array}$ & $\begin{array}{l}\text { Review } \\
\text { methods } \\
\text { prior to } \\
\text { conduct? }\end{array}$ & $\begin{array}{l}\text { Explanation } \\
\text { for } \\
\text { inclusion of } \\
\text { study } \\
\text { designs? }\end{array}$ & $\begin{array}{l}\text { Comprehensive } \\
\text { literature } \\
\text { search? }\end{array}$ & $\begin{array}{l}\geq 2 \\
\text { independent } \\
\text { reviewers } \\
\text { performed } \\
\text { study } \\
\text { selection? }\end{array}$ & $\begin{array}{l}\geq 2 \\
\text { independent } \\
\text { reviewers } \\
\text { performed } \\
\text { data } \\
\text { extraction? }\end{array}$ & $\begin{array}{l}\text { List of } \\
\text { excl. } \\
\text { studies? }\end{array}$ & $\begin{array}{l}\text { Detailed } \\
\text { prescription } \\
\text { of incl. } \\
\text { studies? }\end{array}$ & $\begin{array}{l}\text { RoB } \\
\text { assessment? }\end{array}$ & $\begin{array}{l}\text { Sources } \\
\text { funding } \\
\text { incl. } \\
\text { studies } \\
\text { mention }\end{array}$ \\
\hline $\begin{array}{l}\text { Buzelin et } \\
\text { al. } \\
\text { (1997) [54] }\end{array}$ & $\mathrm{N}$ & $\mathrm{N}$ & $\mathrm{N}$ & $\mathrm{N}$ & $\mathrm{N}$ & $\mathrm{N}$ & $\mathrm{N}$ & $\mathrm{N}$ & $\mathrm{N}$ & $\mathrm{N}$ \\
\hline $\begin{array}{l}\text { Lowe } \\
\text { (1994) [56] }\end{array}$ & $\mathrm{N}$ & $\mathrm{N}$ & $\mathrm{N}$ & $\mathrm{N}$ & $\mathrm{N}$ & $\mathrm{N}$ & $\mathrm{N}$ & $\mathrm{N}$ & $\mathrm{N}$ & $\mathrm{N}$ \\
\hline $\begin{array}{l}\text { Chapple et } \\
\text { al. } \\
\text { (1997) [55] }\end{array}$ & $\mathrm{N}$ & $\mathrm{N}$ & $\mathrm{N}$ & $\mathrm{N}$ & $\mathrm{N}$ & $\mathrm{N}$ & $\mathrm{N}$ & $\mathrm{N}$ & $\mathrm{N}$ & $\mathrm{N}$ \\
\hline
\end{tabular}

$\mathrm{Y}=\mathrm{Yes}, \mathrm{N}=\mathrm{No}, \mathrm{U}=$ Unclear, $\mathrm{RoB}=$ Risk of Bias

Table 5 Critical quality appraisal for included interventional studies according to the Cochrane Collaboration Tool [19] 


\begin{tabular}{|c|c|c|c|c|c|c|c|}
\hline \multirow[t]{2}{*}{ Authors (Year) } & \multirow[t]{2}{*}{ Study Type } & \multirow{2}{*}{$\begin{array}{l}\text { Selection Bias } \\
\text { Randomization } \\
\text { and concealment }\end{array}$} & \multirow{2}{*}{$\begin{array}{l}\text { Performance Bias } \\
\text { Concealment of } \\
\text { intervention/outcome }\end{array}$} & \multirow{2}{*}{$\begin{array}{l}\begin{array}{l}\text { Attrition } \\
\text { Bias }\end{array} \\
\begin{array}{l}\text { Missing } \\
\text { outcome } \\
\text { data }\end{array}\end{array}$} & \multirow{2}{*}{$\begin{array}{l}\text { Detection } \\
\text { Bias } \\
\begin{array}{l}\text { Measurement } \\
\text { of outcome }\end{array}\end{array}$} & $\begin{array}{l}\text { Reporting } \\
\text { Bias }\end{array}$ & \multirow{2}{*}{$\begin{array}{l}\text { Overall risk-of- } \\
\text { bias } \\
\text { judgement }\end{array}$} \\
\hline & & & & & & $\begin{array}{l}\text { Selective } \\
\text { reporting }\end{array}$ & \\
\hline $\begin{array}{l}\text { ALLHAT } \\
(2003)[43]\end{array}$ & $\begin{array}{l}\text { Randomised double-blind } \\
\text { controlled trial }\end{array}$ & LR & LR & LR & LR & LR & LR \\
\hline $\begin{array}{l}\text { Gotoh et al. } \\
(2005)[44]\end{array}$ & $\begin{array}{l}\text { Randomised controlled } \\
\text { trial }\end{array}$ & SC & LR & $\mathrm{HR}$ & SC & SC & $\mathrm{HR}$ \\
\hline $\begin{array}{l}\text { Nishino et al. } \\
(2006)[45]\end{array}$ & $\begin{array}{l}\text { Randomised crossover } \\
\text { trial }\end{array}$ & LR & LR & LR & SC & SC & SC \\
\hline $\begin{array}{l}\text { Oelke et al. } \\
(2014)[46]\end{array}$ & $\begin{array}{l}\text { Randomised double-blind } \\
\text { placebo-controlled trial }\end{array}$ & LR & LR & $\mathrm{HR}$ & LR & LR & $\mathrm{HR}$ \\
\hline $\begin{array}{l}\text { Roehrborn } \\
(2006)[47]\end{array}$ & $\begin{array}{l}\text { Randomised double-blind } \\
\text { placebo-controlled trial }\end{array}$ & LR & LR & $\mathrm{HR}$ & LR & LR & $\mathrm{HR}$ \\
\hline $\begin{array}{l}\text { Yokoyama et } \\
\text { al. }(2011)[48]\end{array}$ & $\begin{array}{l}\text { Randomised controlled } \\
\text { trial }\end{array}$ & LR & LR & $\mathrm{HR}$ & SC & SC & $\mathrm{HR}$ \\
\hline
\end{tabular}

$\mathrm{LR}=$ low risk of bias, $\mathrm{HR}=$ high risk of bias, $\mathrm{SC}=$ some concerns

Table 6 Critical quality appraisal for included cohort studies according to the Critical Appraisal Skills Programme (CASP)

\begin{tabular}{|c|c|c|c|c|c|c|c|c|c|}
\hline $\begin{array}{l}\text { Authors } \\
\text { (Year) }\end{array}$ & $\begin{array}{l}\text { Cohort } \\
\text { studies }\end{array}$ & $\begin{array}{l}\text { Focused } \\
\text { issue? }\end{array}$ & $\begin{array}{l}\text { Acceptable } \\
\text { recruitment } \\
\text { of cohorts? }\end{array}$ & $\begin{array}{l}\text { Accurate } \\
\text { exposure } \\
\text { measurement? }\end{array}$ & $\begin{array}{l}\text { Accurate } \\
\text { outcome } \\
\text { measurement? }\end{array}$ & $\begin{array}{l}\text { Relevant } \\
\text { confounders } \\
\text { identified? }\end{array}$ & $\begin{array}{l}\text { Confounders } \\
\text { considered in } \\
\text { design/analysis? }\end{array}$ & $\begin{array}{l}\text { Follow- } \\
\text { ups } \\
\text { complete? }\end{array}$ & $\begin{array}{l}\text { Follow- } \\
\text { up } \\
\text { period } \\
\text { long } \\
\text { enough? }\end{array}$ \\
\hline $\begin{array}{l}\text { Chrischilles } \\
\text { et al. } \\
\text { (2001) [49] }\end{array}$ & $\begin{array}{l}\text { Retrospective } \\
\text { cohort study }\end{array}$ & Y & $Y$ & $\mathrm{U}$ & $\mathrm{N}$ & $\mathrm{N}$ & $\mathrm{N}$ & $Y$ & $Y$ \\
\hline $\begin{array}{l}\text { Duan et al. } \\
\text { (2018) [50] }\end{array}$ & $\begin{array}{l}\text { Retrospective } \\
\text { cohort study }\end{array}$ & Y & $\mathrm{Y}$ & $Y$ & $Y$ & $Y$ & $\mathrm{Y}$ & $Y$ & $Y$ \\
\hline $\begin{array}{l}\text { Welk et al. } \\
\text { (2015) [51] }\end{array}$ & $\begin{array}{l}\text { Retrospective } \\
\text { cohort study }\end{array}$ & Y & $Y$ & $Y$ & $\mathrm{Y}$ & $\mathrm{Y}$ & $Y$ & $Y$ & $Y$ \\
\hline
\end{tabular}

$\mathrm{Y}=\mathrm{Yes}, \mathrm{N}=\mathrm{No}, \mathrm{U}=$ Unclear, ${ }^{*}$ Results are to be found in table 8

Table 7 Critical quality appraisal for included case-control studies according to the Critical Appraisal Skills Programme (CASP)

\begin{tabular}{|c|c|c|c|c|c|c|c|c|c|c|c|}
\hline $\begin{array}{l}\text { Authors } \\
\text { (Year) }\end{array}$ & $\begin{array}{l}\text { Case- } \\
\text { control } \\
\text { studies }\end{array}$ & $\begin{array}{l}\text { Focused } \\
\text { issue? }\end{array}$ & $\begin{array}{l}\text { Appropriate } \\
\text { method? }\end{array}$ & $\begin{array}{l}\text { Acceptable } \\
\text { recruitment } \\
\text { of cases? }\end{array}$ & $\begin{array}{l}\text { Acceptable } \\
\text { controls? }\end{array}$ & $\begin{array}{l}\text { Accurate } \\
\text { exposure } \\
\text { measurement? }\end{array}$ & $\begin{array}{l}\text { Groups } \\
\text { treated } \\
\text { equally? }\end{array}$ & $\begin{array}{l}\text { Confounders } \\
\text { considered in } \\
\text { design/analysis? }\end{array}$ & $\begin{array}{l}\text { Results } \\
\text { of } \\
\text { study? } \\
\star\end{array}$ & $\begin{array}{l}\text { Believe } \\
\text { in } \\
\text { results? }\end{array}$ & $\begin{array}{l}\mathrm{R} \epsilon \\
\text { ap }\end{array}$ \\
\hline $\begin{array}{l}\text { Hall and } \\
\text { McMahon } \\
\text { (2007) [52] }\end{array}$ & $\begin{array}{l}\text { Case- } \\
\text { control } \\
\text { study }\end{array}$ & $Y$ & $Y$ & $Y$ & $Y$ & $Y$ & $Y$ & $Y$ & & $Y$ & $Y$ \\
\hline $\begin{array}{l}\text { Testa et al. } \\
\text { (2018) [53] }\end{array}$ & $\begin{array}{l}\text { Case- } \\
\text { control } \\
\text { study }\end{array}$ & $Y$ & $Y$ & $Y$ & $Y$ & $Y$ & $Y$ & $Y$ & & $Y$ & $U$ \\
\hline
\end{tabular}

$\mathrm{Y}=\mathrm{Yes}, \mathrm{N}=\mathrm{No}, \mathrm{U}=$ Unclear, ${ }^{*}$ Results are to be found in table 8

\section{Figures}






Figure 1

Preferred Reporting Items for Systematic Reviews and Meta-Analyses (PRISMA) Flow Diagram

"Usage of the PRISMA Statement and Explanatory Document

The PRISMA Statement and the PRISMA Explanation and Elaboration document are distributed under the terms of the Creative Commons Attribution License, which permits unrestricted use, distribution, and reproduction in any medium, provided the original author and source are credited." - retrieved from http://prisma-statement.org/PRISMAStatement/CitingAndUsingPRISMA.aspx on April 25 $5^{\text {th }}, 2020$.

\begin{tabular}{|c|c|c|c|c|c|c|c|c|c|c|c|}
\hline \multirow[b]{2}{*}{ Study or Subgroup } & \multicolumn{3}{|c|}{ Experimental } & \multicolumn{3}{|c|}{ Control } & \multirow{2}{*}{\multicolumn{2}{|c|}{$\begin{array}{ll} & \text { Mean Difference } \\
\text { Weight } & \text { IV, Random, } 95 \% \mathrm{Cl} \\
\end{array}$}} & \multirow{2}{*}{\multicolumn{2}{|c|}{$\begin{array}{c}\text { Mean Difference } \\
\text { IV, Random, } 95 \% \mathrm{Cl}\end{array}$}} & \\
\hline & Mean & SD & Total & Mean & SD & Total & & & & & \\
\hline Gotoh 2005 & 8.7 & 3.5994 & 75 & 17.1 & 6.0849 & 75 & $31.5 \%$ & $-8.40[-10.00,-6.80]$ & & & \\
\hline Nishino 2005 & 9.3 & 3 & 34 & 20.4 & 3.5 & 34 & $31.8 \%$ & $-11.10[-12.65,-9.55]$ & $\rightarrow-$ & & \\
\hline Yokoyama 2011 & 10.7 & 1.4 & 45 & 18 & 1.1 & 45 & $36.6 \%$ & $-7.30[-7.82,-6.78]$ & - & & \\
\hline Total $(95 \% \mathrm{Cl})$ & & & 154 & & & 154 & $100.0 \%$ & $-8.86[-11.14,-6.58]$ & & & \\
\hline \multicolumn{9}{|c|}{$\begin{array}{l}\text { Heterogeneity: } \text { Tau }^{2}=3.63 ; \mathrm{Chi}^{2}=21.46, \mathrm{df}=2(P<0.0001) ;\left.\right|^{2}=91 \% \\
\text { Test for overall effect: } Z=7.61(P<0.00001)\end{array}$} & $\begin{array}{cc}1 & 1 \\
-10 & -5 \\
\text { vours tamsulc }\end{array}$ & $\begin{array}{cc}1 & 1 \\
0 & 5 \\
\text { in Favours }\end{array}$ & $\begin{array}{l}10 \\
0 \text { int }\end{array}$ \\
\hline
\end{tabular}

Figure 2

Meta-analysis of the change in IPSS: tamsulosin $0.2 \mathrm{mg}$ pre to post administration 


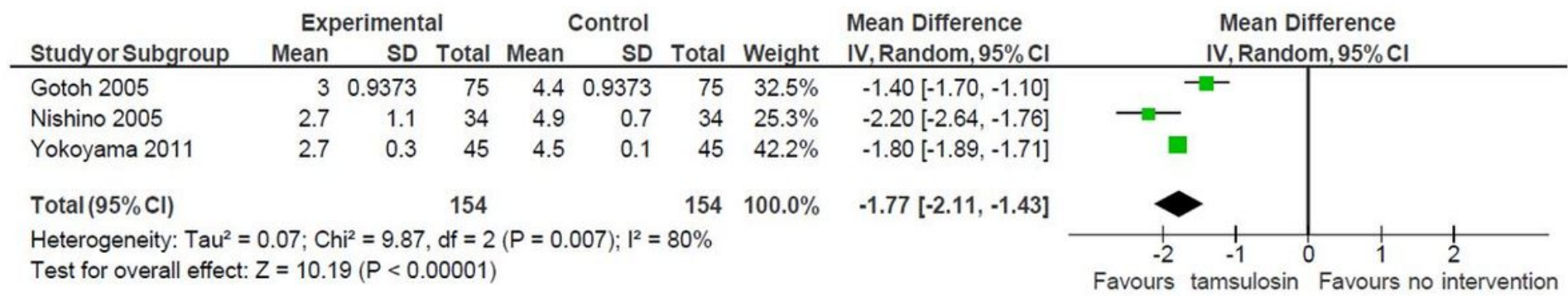

Figure 3

Meta-analysis of the change in QoL-Score tamsulosin $0.2 \mathrm{mg}$ pre to post administration

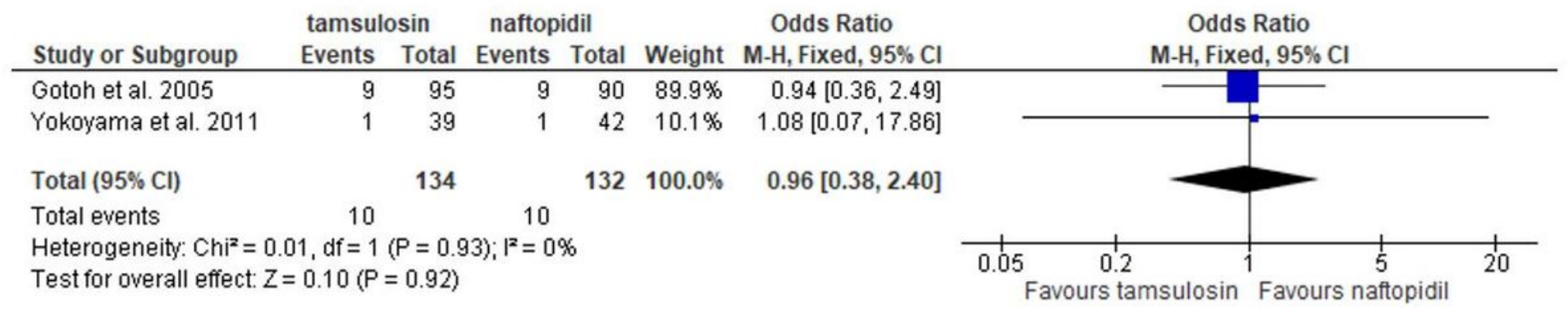

\section{Figure 4}

Meta-analysis on the occurrence of ADEs while treatment with tamsulosin $0.2 \mathrm{mg}$ or naftopidil $50 \mathrm{mg}$

\section{Supplementary Files}

This is a list of supplementary files associated with this preprint. Click to download.

- Additionalfile1.docx

- Additionalfile2.docx

- Additionalfile3.docx

- Additionalfile4.docx

- Additionalfile5.docx 